\title{
Overvaluing Employer-Sponsored Health Insurance
}

\author{
Lauren R. Roth ${ }^{*}$
}

\section{INTRODUCTION}

The implementation of the Patient Protection and Affordable Care Act $(\mathrm{ACA})^{1}$ highlights inequalities between those with employersponsored health insurance (ESI) and those without, even as many without ESI gain new access to affordable insurance. The tax penalties enacted to prevent workers with ESI from entering the individual exchanges for health insurance are a missed opportunity to help eliminate the irrational attachment many with ESI feel towards their health insurance.

I disagree with the tax subsidies that protect ESI and how the Obama administration has succumbed to irrational fears over the potential breakdown of ESI through both rhetoric and recent administrative guidance. The media and scholars remain focused on whether employers will unceremoniously "dump" employees into the health insurance exchanges, and the Obama administration has responded with assurances and tweaks proving that the ACA is simply another layer added on to our existing system of health insurance and not a threat to our attachment to

\footnotetext{
* Acting Assistant Professor, New York University School of Law. Ph.D. 2014, Columbia University; J.D. 2004, Harvard Law School; B.A. 2001, The George Washington University. I am grateful for the helpful comments and conversation provided by Brookes Billman, Amy Monahan, Christopher Robertson, Edward Zelinsky and participants in the Lawyering Scholarship Colloquium at NYU. Thanks also to Calisha Myers for very helpful research assistance.

1. Patient Protection and Affordable Care Act (PPACA), Pub. L. No. 111-148, 124 Stat. 119 (2010), amended by Health Care and Education and Reconciliation Act of 2010, Pub. L. No. 111152, 124 Stat. 1029 (2010) (codified as amended in scattered titles of the U.S.C.) (jointly ACA).

2. The word "dump" is clearly inflammatory, but I use it here at times not only because its use is prevalent in scholarship and media coverage of the issue but also because it demonstrates the emotions and fears involved in the debate over whether individuals will lose their ESI. But cf. David A. Hyman, Response, PPACA in Theory and Practice: The Perils of Parallelism, 97 VA. L. REV. IN BRIEF 83, 100-01 (2011) (taking issue with the use of the "loaded word" dumping in this academic debate particularly because health law and policy scholars associate it with the maligned practice of hospitals transferring uninsured patients to a separate emergency room department - a practice that resulted in Congress passing the Emergency Medical Treatment and Active Labor Act).
} 
ESI. $^{3} \quad$ As long as this attachment remains intact, however, those purchasing health insurance in the exchanges will be worse off. My solution is a more porous border between the exchanges and employersponsored group health plans to breed familiarity and prevent socioeconomic segmentation of the insurance market.

Protection of ESI under the ACA began with the employer mandate to provide acceptable health coverage to employees ${ }^{4}$ or face tax penalties. ${ }^{5}$ The penalties, when coupled with the tax subsidies that make it cheaper for employers to purchase health insurance for employees than it would be for those employees to purchase insurance on their own, will help incentivize employers to continue providing ESI - and prevent those individuals from entering the exchanges without forfeiting valuable tax subsidies gained by purchasing health insurance through an employer.

Even with these added tax penalties and the valuable tax incentives that have sustained ESI for decades, some employers were still frustrated by increasing costs and employee discontent (particularly among less highly compensated workers who struggle to pay for more generous health benefits at this point). ${ }^{6}$ These employers looked to get out of the

3. Of course the additional concern of maintaining ESI to avoid increasing the projected budget for the ACA cannot be denied, but any budget calculations for the ACA should factor in the level of tax revenue foregone through tax exclusions provided to both the employer and employee for ESI premiums and co-insurance. I put the question of how my proposals here would affect the ACA budget aside for now to focus on the ongoing preservation of ESI from a social utility perspective.

4. See infra Part III.A (discussing what the ACA requires of large employers to avoid tax penalties). It must be noted here that employer-sponsored group health plans do not need to provide the essential health benefits that policies sold on the exchanges need to cover. Hyman, supra note 2, at 94 ("Self-insured employers had the political power to get an exemption from the essential health benefits requirements when PPACA was enacted.").

5. See infra Part III.A (discussing the tax penalties assessed to employers that do not offer a group health plan as specified under the ACA to employees). Implementation of the employer mandate that is enforced through these penalties had been postponed until 2015. Valerie Jarrett, We're Listening to Business About the Health Care Law, White House Blog (July 2, 2013, 6:00 PM), http://www.whitehouse.gov/blog/2013/07/02/we-re-listening-businesses-about-health-care-law ("[W]e believe we need to give employers more time to comply with the new rules.").

6. Whether lower-income workers with ESI understand it or not, however, their health insurance costs are subsidized by more highly compensated workers because of ERISA's nondiscrimination provisions. See Christopher T. Robertson, Scaling Cost-Sharing to Wages: How Employers Can Reduce Health Spending and Provide Greater Economic Security, 14 YALE J. HEALTH POL'Y \& ETHICS 239, 293-94 (2014) (theorizing that there is a wage floor for low-income workers that requires highly compensated workers to use part of their tax subsidies to persuade the low-income to participate in an employer's group health plan as required by ERISA's nondiscrimination rules). The benefits to this socioeconomic class are offset by their disproportionate underrepresentation among those with ESI compared to their percentage of the population, however. See JOHn Holahan \& Vicki Chen, The Urban Institute, DeClining

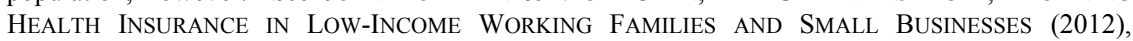


health insurance business and viewed the ACA as a golden opportunity. Parallels to the historical development of private pensions abound. When the Social Security Act passed, employers were able to transfer responsibility for providing pensions to low-income workers to the government by integrating Social Security with their pension plans. ${ }^{7}$ Employees were all guaranteed a baseline income in retirement, and employers could focus on using pensions to reward and retain the highly compensated, making private pensions a human resources tool instead of a social safety net for low-income workers. ${ }^{8}$ A similar path with ESI is predictable in the absence of government interference.

But knowing how attached most Americans with ESI are to their insurance, the media devoted great attention to the possibility that employers might shift all or some employees into the exchanges. ${ }^{9}$ Even with the employer mandate, some employers will make the rational calculation to pay the tax penalty and terminate their group health plans. ${ }^{10}$ This would force employees into individual markets if they want to purchase insurance and break the promise President Obama repeatedly made that employees would be able to keep their health insurance and medical providers. Although this would not be a happy turn of events for President Obama's popularity given the promises made that the ACA was not an attack on ESI, assuming employers are rational actors, the risk of adding to the budget of the ACA and the burden on the exchanges to cover additional individuals is estimable and limited. If an employer pushes all employees - both healthy and sick, low-risk and high-risk for insurers - onto exchanges, then the risk pool will remain roughly the same and the insurance plans offered mainly to those without ESI will be relatively affordable. The healthy will subsidize the cost of insurance for the sick, as they do now under ESI, and there will be little to no adverse

http://www.urban.org/UploadedPDF/412546-Declining-Health-Insurance-in-Low-Income-WorkingFamilies-and-Small-Businesses.pdf.

7. See infra Part III.A.2 (discussing the parallels between Social Security integration and the incentives under the ACA to selectively "dump" low-income workers into the exchanges).

8. See James A. Wooten, The Employee Retirement Income Security Act of 1974: A POLITICAL HISTORY 28-29 (2005) ("The public pension program provided a 'floor of protection' that was too low to sustain a high earner's standard of living.... Perhaps because they wished to defuse business opposition, proponents of OASI seconded the view that public and private pensions played complementary roles.").

9. See infra notes 21-22

10. See Thomas Buchmueller, Colleen Carey \& Helen G. Levy, Will Employers Drop Health Insurance Coverage Because Of The Affordable Care Act?, 32 HeAlth AfF. 1522, 1528 (2013) ("Microsimulation models built on sound economic principles have for the most part predicted relatively small declines in employer-sponsored coverage as a result of health reform, and we believe that these predictions are likely to be correct."). 
selection. ${ }^{11}$ Excluding the value of tax subsidies lost by purchasing insurance on the exchanges instead of through employers, and assuming any forfeited employer subsidies are replaced by higher wages, individuals should be indifferent about where they purchase their plans. ${ }^{12}$

Yet the Obama administration immediately took action to safeguard ESI with additional tax penalties preventing employers from moving employees into the exchanges. The administration was likely concerned not just with the budget for the ACA tax credits and an influx of millions more onto the young and fragile exchanges before the kinks were worked out, but also fearful of breaking promises that ESI would be protected and forcing sudden change on those already satisfied with their health insurance given the tenuous popularity of the ACA. The Internal Revenue Service (IRS) issued guidance clarifying, and then reaffirming, that employers may not subsidize the purchase of individual policies by employees using pre-tax contributions through Health Reimbursement Arrangements (HRAs). ${ }^{13}$ Such action would result in a penalty of $\$ 100$ per employee per day, or $\$ 36,500$ per employee annually, a large penalty ensuring that no rational employer will attempt this cost-containment strategy. ${ }^{14}$

My Article argues that this decision-and tax subsidies for ESI in general-harm health reform efforts because we should instead encourage employers to subsidize their employees' purchase of insurance in the exchanges. Only then can we eliminate the irrational overvaluation of ESI. Using the growing literature on bounded rationality in behavior that counters the traditional law and economics assumption of a rational actor, I assert that this is the perfect area for statutory or regulatory action to debias through the law because of the competing employee bias in favor of individual accounts in employee

11. Adverse selection occurs when high-risk individuals disproportionately enter the pool of insureds and increase the costs of insurance.

12. Assuming complete information, employees should be indifferent about where they purchase their health insurance including the value of the tax subsidies forgone as well since economists believe that employees pay for these subsidies through decreased wages. See Buchmueller, Carey \& Levy, supra note 10, at 1523 ("Economists are in near-unanimous agreement that workers ultimately pay for health insurance through lower wages ... The logic is that employers care about the cost of total compensation, not how compensation is split between wages and benefits; therefore, they will offer insurance only if they can adjust wages to keep total compensation constant."); Craig A. Olson, Do Workers Accept Lower Wages in Exchange for Health Benefits?, 20 J. LAB. ECON. S91 (2002) (demonstrating, using empirical evidence, that women in the sample accepted a $20 \%$ decrease in wages to move from a job without health benefits to one with such benefits).

13. HRAs are tax-favored individual accounts through which employers reimburse employees for medical expenses. See infra Part IV.A (discussing defined contribution financing in healthcare).

14. See infra Part III.B (discussing the recent IRS guidance). 
benefits. While employer preferences show marked rationality in the area of employer-sponsored health insurance, employees have an attachment to ESI based on familiarity that (1) harms exchange-based insurance, and (2) denies employers the ability to use HRAs to subsidize the purchase of insurance by their employees on the exchanges. Employees have been conditioned to the movement for choice in employee benefits through defined contribution plans, ${ }^{15}$ and this background will make it easier to eliminate the overvaluation of ESI.

Section II of this Article will explain why most Americans with ESI overvalue that benefit, including a discussion of the literature on bounded rationality. Fears over the breakdown of ESI and the resulting tax barrier separating those with ESI from the exchanges are based on cognitive biases, and I explain how all involved would benefit from encouraging more people to purchase insurance in the exchanges instead of through their employers. Section III will explore the way that this overvaluation of ESI resulted in the public and scholars fretting that employers will "dump" employees on the exchanges. It will also show how the Obama administration reacted with new restrictions on the use of HRAs. In Section IV, however, I assert that HRAs are a key first step to advance my normative argument that we should subsidize the purchase of health insurance on the exchanges instead of through employers. The defined contribution paradigm that took hold over the last several decades, especially as applied to health financing, conditioned employees to value choice and ownership. The recent IRS guidance contradicts years of government policy favoring the growth of individual accounts. I propose that the restrictions on the use of HRAs to subsidize the purchase of health insurance on the exchanges should be eliminated.

\section{WHY WE OVERVALUE ESI}

Beginning with the 2008 presidential campaign, President Obama helped rally support for his health reform efforts by promising that "if you like your coverage you can keep it." ${ }^{\prime \prime}$ In a speech to the American Medical Association the following year, he emphasized that "no matter

15. "Defined contribution plan" is a phrase originally used in the pension discourse that has made its way into the health and welfare benefit context both intentionally and unintentionally because of the parallels drawn by scholars between shifts in benefits offered by employers in the two areas. The term "individual accounts," drawn from IRAs, is typically used interchangeably when discussing the defined contribution movement, and I will use both here.

16. See David A. Hyman, Employment-Based Health Insurance: Is Health Reform a "Game Changer?”, in ILL. L. AND ECON. RES. PAPERS SERIES 11 (Res. Paper No. LE10-010, 2010). 
how we reform health care, we will keep this promise: If you like your doctor, you will be able to keep your doctor. Period. If you like your health care plan, you will be able to keep your health care plan. Period. No one will take it away. No matter what."17

Although the administration insists that this promise remains truefor the most part- even if it was a simplification, ${ }^{18}$ President Obama has spent the last several years dealing with outrage from individuals and groups losing, or worried about losing, their current health plans. ${ }^{19}$ Scholars and the media have also spent the last few years analyzing the likelihood that employees will lose coverage based largely on rational calculations of whether employers will choose to "pay" penalties under the ACA instead of continuing to "play" the game of offering ESI for workers. $^{20}$ When these analyses were largely complete, they turned to speculation that employers would find ways under the statute to force or incentivize low-income or less healthy employees to instead purchase health insurance on the exchanges in spite of nondiscrimination protections. $^{21}$

17. Remarks by the President at the Annual Conference of the American Medical Association, 1 PUB. PAPERS 818 (June 15, 2009).

18. See Colleen McCain Nelson, Peter Nicholas \& Carol E. Lee, Aides Debated Obama Health-Care Coverage Promise, WALl ST. J., Nov. 2, 2013, at A1.

19. President Obama faced a big challenge in 2013 when insurers began mailing millions of cancellation notices to those that already purchase insurance on the individual market because their low-premium plans did not meet the minimum standards required by the ACA and they did not qualify for "grandfathering." Although the administration dubbed these plans "substandard" and claimed individuals losing their plans would be enrolled in better, cheaper plans, public outrage rose to the point that Democrats (including Bill Clinton) pressured President Obama to step in. His response to allow a temporary reprieve was considered too little too late by many. See Ashley Parker \& Robert Pear, In a Reversal, Obama Moves to Avert the Cancellation of Health Policies, N.Y. Times, Nov. 15, 2013, at A1; Amy Goldstein \& Sean Sullivan, Obama Announces Health-Care Fix to Allow Americans to Keep Plans, WASH. Post, Nov. 14, 2013; Amy Schatz \& Janet Hook, Bill Clinton Calls for Health-Law Changes to Help People Losing Coverage, Wall ST. J., Nov. 13, 2013, at A4; Michael D. Shear \& Robert Pair, Contrite White House Spurns Health Law's Critics, N.Y. TIMES, Oct. 31, 2013, at A17; Glenn Kessler, Obama Health-care Vows were Unequivocally Wrong, WASH. POST, Oct. 31, 2013, at A05.

20. A 2011 survey of 1300 employers conducted by McKinsey \& Company found that $30 \%$ of employers "will definitely or probably stop offering ESI in the years after 2014." Shubham Singhal, Jeris Stueland \& Drew Ungerman, How U.S. Health Care Reform Will Affect Employee Benefits, MCKINSEY \& CO. (June 2011), http://www.mckinsey.com/insights/health_systems_and_services/ how_us_health_care_reform_will_affect_employee_benefits.

21. See Avik Roy, Could Employer Dumping of Health Coverage Reduce the Deficit?, FORBES (Mar. 15 2012, 9:25 PM), http://www.forbes.com/sites/theapothecary/2012/03/15/if-employers-stoppaying-for-health-care-who-wins-maybe-everyone ("A number of credentialed budget wonks... have pointed out that the ACA strongly incentivizes employers to drop coverage for their lower-tomiddle-income employees, because those employees get a better deal by seeking out coverage on the law's new exchanges."); Chriss W. Street, IRS Bars CEOs from Dumping High-Cost Workers on Obamacare, BREITBART (May 29, 2014), http://cdn.breitbart.com/Big-Government/2014/05/28/IRSBars-CEOs-from-Dumping-Sick-Workers-on-Obamacare ("CEOs also expected to be able to 'game 
Employees, for their part, have expressed outrage and panic at sporadic reports that employers will terminate their group health plans. In 2013 and 2014, several large employers, including Walmart, Target, Home Depot, Forever 21, and Trader Joe's, announced that they would no longer offer health insurance to part-time employees, citing health care reform. $^{22}$ These concerns, despite the availability of insurance on the exchanges and a demonstrated decrease in wages paid in exchange for ESI, are a formidable obstacle for health reform.

Those who oppose the ACA and the media, which generates ratings from the panic, stoke the "easily ignited fears of well-insured workers that they will be asked to pay more for less." $" 23$ I agree that fear has been an impediment to health reform and continues now to be an impediment to the implementation of health reform. My concern here, however, is that workers - already being asked by employers to pay more for lessare instead overvaluing all insurance provided through their employers simply because it is provided through their employers. And the government is reinforcing that overvaluation by protecting ESI from erosion to the extent possible.

The result is a stratified system of health insurance in this country where both those with ESI and those without feel that the benefits provided through ESI are superior. As long as ESI is considered to be a superior form of insurance with more generous benefits that are "earned," coverage purchased on the new exchanges will never be as

the system' to save tens of millions of dollars a year by cost shifting the treatment for their chronically sick workers into an Obamacare exchange policy."); Jay Hancock, Employers Eye Moving Sickest Workers to Insurance Exchanges, KAISER HeAlth News (May 7, 2014), http://www.kaiserhealthnews.org/stories/2014/may/07/shifting-employees-to-exchanges.aspx (quoting an executive at a benefits consulting firm who, in regards to the idea that companies may shift workers with high medical costs from the company health plan to the health exchanges, stated, "'It's all over the marketplace... . Employers are inquiring about it and brokers and consultants are advocating for it"').

22. Clare O'Connor, Target Joins Home Depot, Walmart, Others in Cutting Health Care for Part-Timers, Citing Obamacare, ForBes (Jan. 22, 2014, 1:18 PM), http://www.forbes.com/sites/ clareoconnor/2014/01/22/target-joins-home-depot-walmart-others-in-dropping-health-care-for-parttimers-citing-obamacare; Sarah Kliff, Target is Dropping Insurance for Some Because of Obamacare. That Could be Good News for Workers, WASH. POST (Jan. 22, 2014), http://www. washingtonpost.com/blogs/wonkblog/wp/2014/01/22/target-is-dropping-insurance-for-somebecause-of-obamacare-that-could-be-good-news-for-workers/; Steven Greenhouse \& Reed Ableson, Wal-Mart Cuts Some Health Care Benefits, N.Y. TIMES (Oct. 20, 2011), http://www.ny times.com/2011/10/21/business/wal-mart-cuts-some-health-care-benefits.html ("Citing rising costs, Wal-Mart, the nation's largest private employer, told its employees this week that all future part-time employees who work less than 24 hours a week on average will no longer qualify for any of the company's health insurance plans.").

23. Jacob S. Hacker, Putting Politics First, 27 HeALTH AfF. 718, 720 (2008). 
successful because those with other options will avoid it at all costs and lobby the government for increasing protections for ESI. I explain why we overvalue ESI as a precursor to proposing a solution for devaluing ESI.

\section{A. History of ESI Attachment}

The historical development and tax-favored treatment of ESI explains the extent of employee attachment to ESI. ${ }^{24}$ Because few doubt that the attachment runs deep, I include here only a brief background on how employers got into the business of providing employees with health insurance and the stickiness of the current path.

Prior to World War II, about 3\% of American workers had employer-provided health insurance. ${ }^{25}$ Although welfare capitalists experimented with providing health benefits as a way to discourage unionization and retain employees, ${ }^{26}$ it was not until World War II that ESI grew and became entrenched. ${ }^{27}$

Several factors significantly contributed to the growth of ESI at that time. First, during World War II, the Office of Price Administration put in place wage controls but excluded fringe benefits, such as payments for worker health insurance, from the definition of wages. ${ }^{28}$ As a result, employers increasingly used health benefits (among other fringe

24. See Jacob S. Hacker, The Divided Welfare State: The Battle over Public and PRivate Social BenEFITS IN THE United StATES (2002) (explaining how path dependence shapes our current system of health insurance).

25. See Kathryn L. Moore, The Future of Employment-Based Health Insurance After the Patient Protection and Affordable Care Act, 89 NEB. L. REV. 885, 887-88 (2011). While only 12.3 million Americans had health insurance in 1940, that number jumped to 122.5 million by 1960 . Melissa A. Thomasson, From Sickness to Health: The Twentieth-Century Development of U.S. Health Insurance, 39 EXPLORATIONS IN ECON. HIST. 233, 233-34 (2002). By 1958, 75\% of Americans had health insurance. Id. at 241.

26. See Stuart D. Brandes, American Welfare Capitalism, 1880-1940 (1976); see also JeNNifER Klein, For All These Rights: Business, LABOR, AND THE SHAPING OF AMERICA's Public-Private Welfare State (2003).

27. See Brendan S. Maher, Some Thoughts on Health Care Exchanges: Choices, Defaults, and the Unconnected, 44 CONN. L. REV. 1099, 1102-03 (2012) ("As the science of medicine became more advanced, it offered more cures, for which more people were willing to pay (and pay more), than the number of people who were willing to pay (and the amounts they were willing to pay) for the more primitive 'medicine' of times past."); Thomasson, supra note 25, at 236-37 (discussing how scientific advances spurred increased demand for care by physicians and hospitals and thus increased costs for these services and the need for insurance).

28. Moore, supra note 25 , at 889. 
benefits) to attract workers in a tight labor market. ${ }^{29}$ Over time, employees grew accustomed to health insurance provided by employers.

Second, when veterans re-entered the workforce after the war, they brought with them familiarity with government insurance and a new value for such benefits provided through employment. ${ }^{30}$

Third, unions also influenced the growth of ESI in the 1940s and 1950 s. $^{31}$ In the late 1940 s, unions began to push for health insurance during collective bargaining and helped form multiemployer plans that covered all employees within a particular industry. ${ }^{32}$ Multiemployer plans were particularly attractive to employees because they allowed employees to keep the same health insurance while changing jobs (as long as the new job was covered by the same multiemployer plan). ${ }^{33}$ Employers increased their health coverage more broadly to discourage further unionization. ${ }^{34}$

Finally, the tax code has long motivated the growth of ESI. A 1943 IRS ruling stated that premiums paid by employers for employee health insurance plans were excluded from employees' income, and employers could also deduct the premiums as ordinary and necessary business expenses and exclude them for the purpose of other payroll taxes - a double tax advantage. ${ }^{35}$ With marginal tax rates as high as $85 \%$ during World War II, this meant employees had a choice between 15 cents of income or a full dollar of health insurance. ${ }^{36}$ When the revenue ruling was withdrawn in 1953, the tax exemption was formally added to the

29. Id. A 1945 War Labor Board decision that employers could not alter or terminate insurance during the contract period increased worker security in their health benefits and thus demand for these benefits. See Thomasson, supra note 25, at $240 \mathrm{n} .15$.

30. Moore, supra note 25, at 892; Gerald Markowitz \& David Rosner, Seeking Common Ground: A History of Labor and Blue Cross, 16 J. HEALTH POL. POL'Y \& L. 695, 696 (1991).

31. See David Rosner \& Gerald Markowitz, The Struggle over Employee Benefits: The Role of Labor in Influencing Modern Health Policy, 81 MiLBANK Q. 45 (2003) (discussing the declining role of unions in health policy in the second half of the twentieth century).

32. Moore, supra note 25 , at 891.

33. See Wooten, supra note 8, at 37 (discussing dynamics of multiemployer pension plans which operate by "pooling risks and resources ... that might be local, regional, or even national in scope").

34. See Moore, supra note 25, at 891-92; see also Inland Steel Co. v. NLRB, 170 F.2d 247 (7th Cir. 1948), cert. denied, 336 U.S. 960 (1949) ("While, as the Company has demonstrated, a reasonable argument can be made that the benefits flowing from such a plan are not 'wages,' we think the better and more logical argument is on the other side, and certainly there is, in our opinion, no sound basis for an argument that such a plan is not clearly included in the phrase, 'other conditions of employment."); Markowitz \& Rosner, supra note 30 (discussing union involvement in the growth of Blue Cross hospital insurance to secure improved worker medical care).

35. Moore, supra note 25 , at 889 .

36. Id. at $889-90$. 
Internal Revenue Code (IRC), ${ }^{37}$ demonstrating that Americans had become accustomed to ESI and the tax incentives that supported it. ${ }^{38}$

In addition to the demand-side factors described above, an increase on the supply side also promoted growth at this time. Hospitals and physicians formed Blue Cross and Blue Shield plans respectively to provide pre-payment plans for individuals in need of insurance to pay for medical expenses. ${ }^{39}$ The success of these plans pushed commercial insurers into the arena. ${ }^{40}$

These crucial changes during and after World War II resulted in tremendous growth of ESI and the resulting decades in which the vast majority of American workers grew accustomed to receiving taxsubsidized health insurance through employers. ${ }^{41}$ The influence of path dependence on employee attachment to ESI and fears over its change or elimination cannot be overstated. Political scientist Jacob Hacker applies the notions of path dependence and critical junctures to the study of the development of the American welfare state. ${ }^{42}$ Hacker first argues that path dependence indicates that "timing matters" since policy decisions made early in the path have a larger influence than those made later. ${ }^{43}$ Second, path dependence assumes a significant amount of "institutional inertia" that continues policies put in place at an earlier time. ${ }^{44}$

To put it simply, it is difficult to leave the current path. Once the country started down the path of ESI, it developed institutions such as tax-incentives that further encouraged ESI. Similarly, tax-subsidized

37. Id. at 890 ; I.R.C. $\S \S 105,106$ (2012).

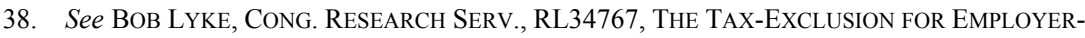
Provided Health Insurance: Policy Issues Regarding the Repeal Debate (2008); Comment, Employer Health or Accident Plans: Taxfree Protection and Proceeds, 21 U. CHI. L. REV. 277 (1954).

39. Thomasson, supra note 25, at 234.

40. See id. at 234, 237-40; Markowitz \& Rosner, supra note 30.

41. At $\$ 131.7$ billion, the tax exclusion for employer contributions to healthcare, health insurance, and long-term care insurance remains the largest tax expenditure in the U.S. See STAFF OF JOINT COMM. ON TAXATION, 112TH CONG., ESTIMATES OF FEDERAL TAX EXPENDITURES FOR FisCAL YeARS 2012-2017, at 38 (Comm. Print 2013). The tax exclusion is projected to remain the largest expenditure, with an estimate of $\$ 143$ billion for 2014. See STAFF OF JoInT Comm. ON TAXATION, 113Th CONG., ESTIMATES OF FEDERAL TAX EXPENDItURES FOR Fiscal YeARs 20142018, at 31 (Comm. Print 2014).

42. See HACKER, supra note 24, at 52-62; see also Paul Pierson, Not Just What, but When: Timing and Sequence in Political Processes, 14 StUd. AM. Pol. Dev. 72 (2000); Paul Pierson, Increasing Returns, Path Dependence, and the Study of Politics, 94 AM. POL. SCI. REV. 251 (2000).

43. See HACKER, supra note 24, at 53 (discussing effects of path dependence on public policy).

44. Id. at 52-55; see also James Mahoney, Path Dependence in Historical Sociology, 29 THEORY \& SOC'Y 507, 512 (2000) (discussing self-reinforcing sequences). Even "trivial events" may have large effects when "self-reinforcing mechanisms - large set-up or fixed costs, learning effects, coordination effects, adaptive expectations - are present." HACKER, supra note 24, at 53. 
health insurance drove up medical costs further and increased the importance of insurance coverage. ${ }^{45}$

The path has also been sticky for employers. The growing cost of ESI and employers' reluctance to be in the healthcare business are two reasons behind the movement for health reform, but attachment to ESI and a tax system that feeds that attachment remain. There are a multitude of books and articles lamenting or defending (and sometimes both) the continuing strength of ESI given its "accidental" 46 growth during and after World War II and the supposed lack of connection between employment and employees' health. ${ }^{47}$

For a long time, employers were indifferent between offering employees wages or fringe benefits - seeking the optimal combination to attract and retain the best-qualified workforce. Employees may not have understood that they were receiving lower wages in exchange for the health benefits, but they valued the benefits and tax incentives that allowed employers to offer more generous health plans. For example, the average employee essentially has the option of receiving $\$ 1$ of wages or $\$ 1.33$ of health benefits (excluding discussion of the inflationary pressures that the tax subsidies have on the cost of health insurance). ${ }^{48}$

But then health costs rose and employers were forced to make difficult choices: employers could pay more, or have their employees pay more or receive less and suffer the consequences. Employers forced

45. See Amy B. Monahan, Why Tax High-Cost Employer Health Plans?, 65 TAX L. Rev. 749, 749-50 (2012) ("The tax preference for employer-sponsored health insurance ... is thought to contribute to rising health expenditures and health insurance premiums by causing individuals to purchase coverage that is too generous (a problem referred to in this Article as the problem of 'overinsurance').").

46. David Blumenthal, Employer-Sponsored Health Insurance in the United States-Origins and Implications, 355 NEW ENG. J. MED. 82, 82, 145 (2006) ("The heavy reliance on employersponsored insurance in the United States is, by many accounts, an accident of history that evolved in an unplanned way and, in the view of some, without the benefit of intelligent design."). But cf. JACOB S. HACKER, THE GREAT RiSK SHIFT: THE NEW ECONOMIC INSECURITY AND THE DECLINE OF THE AMERICAN DREAM 144-46 (2008) (stating that ESI became entrenched as employers found private health insurance to be "an increasingly good deal: It bought them loyalty, healthier workers, and federal tax breaks").

47. See, e.g., David A. Hyman \& Mark Hall, Two Cheers for Employment-Based Health Insurance, 2 YALE J. HEALTH POL'Y L. \& ETHICS 23, 23 (2001) (defending ESI in an article that opens with the line: "Employment-based health insurance is the Rodney Dangerfield of health policy: it gets no respect from anyone"); Alain C. Enthoven, Consumer-Centered vs. Job-Centered Health Insurance, 57 HARV. BUS. REV. 141 (1979) (arguing that ESI results in a lack of competition that increases health care costs).

48. See Buchmueller, Carey \& Levy, supra note 10, at 1523 ("For a typical worker in the 15 percent tax bracket, the tax exclusion reduces the cost of insurance by roughly one-third. For higherincome workers, the subsidy is even greater."). 
employees to pay a larger share of premiums for their health insurance, ${ }^{49}$ increased deductibles and co-payments, ${ }^{50}$ and increasingly turned to coinsurance. $^{51}$ Employers also offered less generous health plans, including high-deductible health plans and tax-favored individual accounts, to assist employees with routine health expenses. ${ }^{52}$ Employees expressed outrage while simultaneously maintaining high levels of satisfaction with their health plans because of the lack of better or even comparable alternatives that could be purchased with pre-tax dollars. ${ }^{53}$

The systemic difficulties associated with deviating from ESI have been thoroughly explored in the literature, but this Article asserts that scholars have largely ignored the way in which the psychology of fear

49. Annual premiums for health benefits through employers rose $80 \%$ from 2003 to an average of $\$ 5,884$ for single coverage and $\$ 16,351$ for family coverage in 2013. Gary Claxton et al., Health Benefits in 2013: Moderate Premium Increases in Employer-Sponsored Plans, 32 Health AfF. 1667,1669 (2013). In 2013, the average worker paid $18 \%$ of the premium for single coverage and $29 \%$ of the premium for family coverage. Id. Although the percentage of premiums paid by workers has not increased dramatically in the last decade (the average worker paid $16 \%$ for single and $27 \%$ for family coverage in 2003), the enormous increase in premium costs overall means both employer and employee are paying substantially more in real dollars. THE KAISER FAM. FOUND. \& Health Res. \& Educ. TR., Employer Health Benefits: 2003 AnNual Survey 4 (2003), http://kaiserfamilyfoundation.files.wordpress.com/2013/04/kaiser-family-foundation-2003employer-health-benefits-survey-full-report.pdf.

50. The percentage of employees enrolled in a plan with a high annual deductible ( $\$ 1000$ or more) has tripled in the past five years, from $9 \%$ in 2008 to $28 \%$ in 2013 ; the percentage with a deductible of $\$ 2000$ or more for single coverage quadrupled in the same time period, jumping from $2 \%$ to $8 \%$. The Kaiser Fam. Found. \& Health Res. \& Educ. Tr., EMPloyer Health Benefits: 2013 ANNUAL SURVEY 110-11, Exs. 7.9 \& 7.10 (2013), http://kaiserfamilyfoundation. files.wordpress.com/2013/08/8465-employer-health-benefits-2013_section_72.pdf. Copayments have also increased. Id. In $2008,40 \%$ of covered employees had copayments of $\$ 10-\$ 20$. Id. at 130, Ex. 7.29. In 2013, that percentage was down to $22 \%$, with the majority (55\%) of workers paying $\$ 20-\$ 30$ per physician office visit and $21 \%$ of workers paying $\$ 30-\$ 40$ (up from $8 \%$ in 2008). Id.

51. In 2008, 11\% of covered employees had coinsurance. THE KAISER FAM. FOUND. \& Health Res. \& Educ. Tr., Employer Health Benefits: 2008 AnNual Survey 3 (2008), http://kaiserfamilyfoundation.files.wordpress.com/2013/04/7790.pdf. In 2013, 20\% of covered employees had plans that required co-insurance. THE KAISER FAM. Found., 2013 ANNUAL SURVEY, supra note 50, at 122, Ex. 7.25.

52. In $2003,5 \%$ of employers offered high-deductible insurance plans. THE KAISER FAM. Found., 2003 ANNUAL SuRVEY, supra note 49, at 46, Exhibit 2.7. By 2013, most covered employees had high-deductible health plans: $38 \%$ of covered workers had deductibles of $\$ 1000$ or more and $15 \%$ had deductibles of $\$ 2000$ or more. THE KaISER FAM. FounD., 2013 AnNuAL SURVEY, supra note 50, at 109, Exhibit 2.8.

53. In a 2013 survey, $51 \%$ of workers with health insurance coverage said they were extremely or very satisfied with their current plans, and another $37 \%$ were somewhat satisfied. Paul Fronstein, 2013 Health and Voluntary Workplace Benefits Survey: Nearly 90\% of Workers Satisfied with Their Own Health Plan, but 55\% Give Low Ratings to Health Care System, EMP. BENEFITS RES. INST. NotES 1 (Sept. 2013), http://www.ebri.org/pdf/notespdf/EBRI_Notes_09_Sept-13_WBS-Rep Rts2.pdf. Fifty-five percent rated the health care system as fair or poor, however, mainly because of rising costs. $I d$. 
has hindered reform and proposes solutions to this form of "individual" path dependence.

\section{B. Bounded Rationality in ESI and Debiasing Through the ACA}

As discussed above, when health insurance took hold in this country, it was connected to employment. Prior to reaching retirement age and accessing Medicare, "good" insurance was available only to those who worked-and others did without insurance or suffered the stigma and less generous terms of Medicaid. The traditional American value of "earning" social welfare benefits so explicit in our Social Security system is also present in our ESI system. ${ }^{54}$

For this and other reasons drawn from the law and behavioral science literature, I argue that Americans overvalue their ESI regardless of the precise benefits offered and wages forfeited as a result. Legal scholarship has increasingly analyzed how human behavior differs from the assumption of much economics literature that humans behave with unbounded rationality. ${ }^{55}$ These works seek to answer what-if anything - the law should do about these deviations. In this subsection, I explore how individual attachment to ESI is a case of bounded rationality and argue that the law can and should reduce or eliminate the cognitive biases that cause individuals to make inefficient calculations regarding the importance of retaining ESI.

\section{Bounded Rationality}

In recent years, legal scholars have done battle with the traditional rational choice theory that underlies most law and economics literature. ${ }^{56}$

54. See Frances fox Piven \& Richard A. Cloward, Regulating the Poor: The FunCtions OF Public Welfare 20 (1971) ("Direct relief [during the Depression] was viewed as a temporary expedient, a way of maintaining a person's body, but not his dignity; a way of keeping the populace from shattering in despair, discontent, and disorder, at least for a while, but not of renewing their pride, of bringing back a way of life. For their way of life had been anchored in the discipline of work, and so that discipline had to be restored.").

55. See, e.g., Russell B. Korobkin \& Thomas S. Ulen, Law and Behavioral Science: Removing the Rationality Assumption from Law and Economics, 88 CALIF. L. REV. 1051 (2000) (explaining why the rationality assumption leads to unsatisfying policy prescriptions and proposing a new scholarship paradigm - law and behavioral science); Christine Jolls, Cass R. Sunstein \& Richard Thaler, A Behavioral Approach to Law and Economics, 50 STAN. L. REV. 1471 (1998); see also Maher, supra note 27, at 1106 ("Insurance purchasing is widely believed to be an area in which humans are extremely susceptible to cognitive biases and flawed decision-making.").

56. See Korobkin \& Ulen, supra note 55 (arguing that law and economics scholarship should be transformed into law and behavioral science scholarship that modifies the traditional assumption of rationality underlying rational choice theory). 
Scholars argue first that individuals are "boundedly rational"-meaning that "[t]o save time, avoid complexity, and generally make dealing with the challenges of daily life tractable, actors often adopt decision strategies or employ heuristics that lead to decisions that fail to maximize their utility. $" 57$ To put it more simply, individuals have a limited ability to absorb all possible information about various choices available and must therefore figure out which of that information to include in their decision making and how to weigh it. ${ }^{58}$

The deviation from unbounded rationality that I am concerned with here is the deviation from expected utility theory. ${ }^{59}$ Nobel Prize winner Daniel Kahneman and Psychology Professor Amos Tversky theorized in 1979 that individuals are focused on how outcomes involve change from a starting point-instead of a neutral analysis of the benefits and drawbacks of the outcome itself. ${ }^{60}$ Their "prospect theory" argues that people demonstrate loss aversion by "weigh[ing] losses more heavily than gains." ${ }^{\prime 61}$

Prospect theory is based on the endowment effect, or the idea that individuals value an item more highly if they already own it than if they have to purchase it. ${ }^{62}$ Because people weigh losses so heavily, it matters

57. Id. at 1143 .

58. Id. Scholars argue that preferences are also determined by "context"-meaning that "[c]hoices are not made merely by comparing decision outcomes; situational variables are critical inputs into decision making." Id.

59. The other category of deviation from unbounded rationality is judgment errors. Christine Jolls \& Cass R. Sunstein, Debiasing Through Law, 35 J. LegAL STUD. 199, 203-05 (2006); see also Korobkin \& Ulen, supra note 55, at 1062 (discussing how expected utility theory is considered "thin" rational choice theory because it does not state what individuals' goals or preferences are).

60. See Daniel Kahneman \& Amos Tversky, Prospect Theory: An Analysis of Decision Under Risk, 47 ECONOMETRICA 263, 274 (1979) (demonstrating that "people normally perceive outcomes as gains and losses, rather than as final states of wealth or welfare" and start from a neutral reference point of the status quo).

61. Jolls \& Sunstein, supra note 59, at 205; see also Kahneman \& Tversky, supra note 60, at 279 ("The aggravation that one experiences in losing a sum of money appears to be greater than the pleasure associated with gaining the same amount."); see Amy B. Monahan, On Subsidies and Mandates: A Regulatory Critique of ACA, 36 J. CORP. L. 781, 796 (2011) (arguing that loss aversion may reduce the likelihood that individuals will choose to pay the tax penalty instead of paying for health insurance since paying the mandate "represents a pure loss").

62. See Charles R. Plott \& Kathryn Zeiler, The Willingness to Pay-Willingness to Accept Gap, the "Endowment Effect," Subject Misconceptions, and Experimental Procedures for Eliciting Valuations, 95 AM. ECON. REV. 530, 530 n.1 (2005) (explaining that the gap between how much someone is willing to pay for an item and the amount they are willing to accept for an item is attributed by some to loss aversion and has thus come to be termed the "endowment effect"); Daniel Kahneman, Jack L. Knetsch \& Richard H. Thaler, Experimental Tests of the Endowment Effect and the Coase Theorem, 98 J. POL. ECON. 1325, 1326 (1990) (noting that Richard H. Thaler coined the phrase "endowment effect" to represent the increased value that is bestowed upon a good when it becomes part of an individual's endowment). 
significantly if outcomes are framed as losses or gains. ${ }^{63}$ This matters "because the endowment effect is often linked to a desire by entitlement holders to avoid regretting a bad decision to engage in a transaction (sale of the entitlement)." ${ }^{64}$ Legal scholarship on the endowment effect and its role in the law has proliferated. ${ }^{65}$

Few doubt that attachment to ESI is a significant impediment to a dramatic overhaul of our healthcare system. But attachment to ESI is wrapped up in feelings about the value of employment, attachment to particular doctors covered by the plan's network, familiarity with the procedures for payment or reimbursement under a particular plan, and much more.

Several experimental findings show why the endowment effect is increased in the health insurance context. ${ }^{66}$ The effect is amplified where: (1) the value of the entitlement is uncertain; (2) the entitlement is thought of as a "baseline" instead of a "bonus"; (3) the "evolutionary salience" of the entitlement is high (close connection between the item and survival); (4) the entitlement is assessed for its "use value" (e.g., the value of receiving quality medical care for a low to moderate cost) instead of for its "exchange value" (e.g., what such health insurance

63. Jolls \& Sunstein, supra note 59, at 205-06. However, the endowment effect is significantly reduced, if not altogether eliminated, when the decision maker is acting on behalf of another. Jennifer Arlen, Matthew Spitzer \& Eric Talley, Endowment Effects Within Corporate Agency Relationships, 31 J. LEGAL STUD. 1, 5 (2002).

64. Jolls \& Sunstein, supra note 59, at 223.

65. See Russell Korobkin, The Endowment Effect and Legal Analysis, 97 Nw. U. L. REV. 1227, 1236 (2003) (explaining that the existence and magnitude of the endowment effect depends on the context so that when a good or entitlement is earned, the endowment effect is more pronounced). But recent scholarship has called into question the existence of an endowment effect. Professors Gregory Klass and Kathryn Zeiler argue that legal scholars have ignored other potential reasons for the desire not to part with entitlements. See Gregory Klass \& Kathryn Zeiler, Against Endowment Theory: Experimental Economics and Legal Scholarship, 61 UCLA L. REV. 2 (2013). The authors also note that:

In order to argue that a given legal entitlement was likely to affect people's preferences, one had to tell a story about why that entitlement was likely to result in a change in valuation. That story might include causes cognizable under traditional economic theory, such as wealth effects or increased knowledge about the object of the entitlement. It might involve biases or heuristics, such as buy-low/sell-high bargaining habits. Or it might involve observations about the affective aspects of ownership, such as the attachment people feel toward some possessions, the felt need to remove some spheres of life from the marketplace, or the tendency to treat legal assignments as presumptively Id. at 26 .

correct. The effect of endowment theory has been to flip the burden of persuasion.

66. See Justin L. Bernstein, Controlling Medicare with Lessons from Endowment Effect Experiments, 49 CAL. W. L. REV. 169, 174-78 (2013) (describing how "perception" and "context" affect the strength of the endowment effect in order to reduce the endowment effect and its consequences for Medicare). 
would cost on an open market); and (5) the entitlement is held for a long time period. ${ }^{67}$

Even a quick application of these findings to the ESI context shows why individuals are so protective of their employment-based coverage. First, the value of ESI is uncertain. Determining the value of ESI is difficult given that the value of tax subsidies depends on the employee's bracket, and the precise reduction of wages used to "purchase" this benefit is difficult to quantify. Second, after many years, ESI has come to be viewed as a baseline benefit to which those who work are entitled-particularly for middle and high-income workers. Third, in a time where the connection of high-quality medical care to longevity is clear and poor health insurance frequently results in ruinous financial consequences, the "evolutionary salience" of health insurance is high. Fourth, employees overvalue ESI because they focus on what ESI does for them - the value of having access to medical care-instead of the dollars and cents cost of purchasing a comparable insurance policy elsewhere. Finally, the majority of full-time workers have had ESI for most or all of their careers and have often been participants of the same health plans for many years - increasing their connection to this benefit.

Those with ESI demonstrate an inefficient attachment to their insurance, as manifested in recent outrage at the thought that employers may force or push some or all of their employees into the individual exchanges created under the ACA. Most employees know little about how their insurance plans would be different on the exchanges or the extent of any possible decrease in employer subsidies not offset by higher wages from employers no longer paying those subsidies. Despite this, they fear the loss of their ESI with a ferocity that doomed previous efforts at health reform. ${ }^{68}$

67. See id. Bernstein's article describes seven experimental findings that amplify the endowment effect. I have chosen five that I believe are most relevant in the ESI context.

68. See Jonathan Oberlander, Health Care Reform's Failure: The Song Remains the Same, 24 Health AfF. 1679, 1680 (2005) ("One reason that those with a stake in maintaining the status quo have been able to shake public support for particular reforms is that the status quo does not seem like a bad fallback option for the comfortably insured."). One fruitful area of research would be to compare the satisfaction levels of individuals with substantially similar health insurance policies purchased on the exchange with those provided through employment. If employees with coverage through ESI exhibit higher levels of satisfaction for the same policies, then insurance provided through employment is valued more highly even if the policy terms are the same. Kahneman \& Tversky, supra note 60 , at 286. Kahneman and Tversky state that any theory of insurance behavior should include more than just a rational calculation of the probabilities of risks (i.e., health risks) and include factors such as the benefit of "security," the norm of "prudence," the ability to pay for insurance in small installments over a long time horizon, and information and misinformation on the occurrence of risks (among other factors). $I d$. 


\section{Debiasing}

Showing that individuals are boundedly rational when it comes to retaining their ESI, however, does not necessarily imply that the law needs to intervene. While traditional law and economics literature is "antipaternalistic"-advocating unrestricted choice with unfettered access to relevant information necessary to make that choice meaningful - the recent focus on bounded rationality "pushes toward a sort of anti-antipaternalism - a skepticism about antipaternalism, but not an affirmative defense of paternalism." ${ }^{\text {"9 }}$ Professor of Behavioral Science and Economics Richard Thaler and Law Professor Cass Sunstein, for example, argue that "there is no such thing as a 'neutral' design." 70 They seek to initiate a new movement called "libertarian paternalism." ${ }^{71}$ As part of their movement, it is permissible to help people improve their lives through making informed decisions with a "nudge" - or many nudges. ${ }^{72}$

Debiasing, or nudging, through substantive law suggests that in some cases it may be desirable to "reform"-or manipulate - the "substance of law" to allay the effects of bounded rationality. ${ }^{73}$ This method involves eliminating or reducing the commonly observed gap between "individuals' willingness to accept — the amount at which they would sell an entitlement-[and] their willingness to pay - the amount they would pay to purchase the same entitlement." 74

One example of debiasing through law provided by Christine Jolls and Cass Sunstein is a comparison of intellectual property law in Europe and the United States. Those with intellectual property entitlements can be subject to a property rule as in the United States (i.e., they need not allow others to use their entitlement unless they agree-usually after demanding a steep price) or a liability rule as in Europe (i.e., they may be required to permit others to use their entitlement and then they will be

\footnotetext{
69. Jolls, Sunstein \& Thaler, supra note 55, at 1541.

70. See Richard H. Thaler \& Cass R. Sunstein, Nudge: Improving Decisions About HEALTH, WEALTH, AND HAPPINESS 3-4 (2008) (arguing that "[g]ood architects realize that although they can't build the perfect building, they can make some design choices that will have beneficial effects").

71. Id. at 5. Thaler and Sunstein recognize the backlash likely to result from their use of this phrase but argue in favor of intervention that promotes informed choice.

72. See id. at 6 (explaining that employers and the government are key choice architects who nudge employees with respect to healthcare decisions).

73. Jolls \& Sunstein, supra note 59, at 202.

74. Id. at 220 .
} 
compensated with set damages). ${ }^{75}$ Evidence shows that the use of a liability rule in Europe brings willingness to accept down to willingness to pay, likely because there is less of a feeling of ownership over the entitlement and thus there are less emotions involved-allowing rationality back in to the decision making process. ${ }^{76}$

Jolls and Sunstein's discussion of debiasing through agency law is particularly relevant in the context of employers making decisions regarding available health insurance options on behalf of employees. There is evidence that managers acting on behalf of a corporation through an agency relationship demonstrate almost no endowment effect - meaning they do not demonstrate a willingness to accept over a willingness to pay. ${ }^{77}$ This evidence is likely the result of both the business context and the agency relationship. ${ }^{78}$ The business context makes it less likely that individuals will have an exaggerated willingness to accept since the business must sell to survive. ${ }^{79}$ The agency relationship also is likely to reduce or eliminate the endowment effect because it reduces the personal investment in the entitlement and thus the emotions resulting in a fear of loss. ${ }^{80}$

The evidence that business managers show little to no endowment effect helps explain why employers appear to be more willing to make rational decisions after the ACA regarding whether to continue offering ESI. They seem ready to make financial calculations that would lead to a more efficient and less stratified health financing system-except for impediments put in place by government actors and employees.

There are of course problems with attempts to debias boundedly rational individuals. One problem with debiasing for deviations from the expected utility theory is that the individuals show no clear error-there is no obvious mistake. ${ }^{81}$ Perhaps individuals simply prefer to receive health insurance through their employers. The benefits then feel "earned." There are also economies of scale because administrative expenses for insurance companies are reduced when insurance is offered to a large group through an employer instead of on the individual market.

\footnotetext{
75. Id.

76. Id. at 220-22 (focusing on the situations in which either willingness to accept or willingness to pay should be the measure of value used (based, of course, on judgments of regulators, which are themselves subject to bias)).

77. Id. at 223 .

78. Id.

79. Id.

80. Id. at 223-24

81. Id. at 219 .
} 
Employees may believe that employers can more quickly and easily decide what type of health coverage they need since it requires wading through information and making a calculation as to the risk that employees will need coverage for various types of healthcare.

There is nothing wrong per se with a system where employees want employers to offer health insurance for these reasons and thus overvalue the benefit, unless it: (1) harms exchange-based insurance and (2) denies employers the ability to use HRAs to subsidize the purchase of insurance by their employees on the exchanges. Even if both employers and employees are satisfied with the system, I here make a normative argument that third parties outside the ESI relationship (i.e., those who purchase exchange-based insurance) should not be harmed by the continuation of the current ESI system. I also argue that employees would likely not be happy if they fully understood the tradeoffs and distortions on their health insurance costs and policies resulting from tax subsidies and penalties, and the tradeoff between employer subsidies for health insurance costs and wages. ${ }^{82}$

One reason to debias in spite of concerns about government manipulation is that it promotes choice - a central component of the defined contribution revolution discussed above - mitigating against concerns of paternalism. ${ }^{83}$ "[A] special virtue of debiasing through law is that ... it maximizes the preservation of people's opportunity to make choices. Instead of blocking decisions, it is preferable to attempt to

82. "A more fundamental concern with debiasing through law involves individual autonomy. When government is engaged in (what it considers to be) debiasing, there is a risk that it will manipulate its citizens to serve its own objectives." Id. at 231. With debiasing, the government attempts to alter the way people think about (in this case) their health financing and their behavior based on that framework - resulting in normative considerations of whether this is advisable. $I d$. at 202-03. Normative concerns of debiasing are exacerbated by the fact that government actors who would in the case of health insurance seek to debias individuals are themselves subject to bounded rationality regarding the value of ESI. See id. at 233 ("No less than ordinary people, bureaucrats use heuristics and are subject to predictable biases; they are also susceptible to the influence of powerful private groups with stakes in the outcome. In fact, the very accountability of bureaucrats suggests that they will be affected by the bounded rationality of the citizenry.").

83. See id. at 202 ("More generally, rules and institutions might be, and frequently are, designed to curtail or even entirely block choice in the hope that legal outcomes will not fall prey to problems of bounded rationality."); Jeffrey J. Rachlinski, The Uncertain Psychological Case for Paternalism, 97 Nw. U. L. REV. 1165 (2003) (expressing concern that paternalism abrogates individual choice). But see Mario J. Rizzo \& Douglas Glen Whitman, Little Brother is Watching You: New Paternalism on the Slippery Slopes, 51 ARIz. L. REV. 685 (2009) (arguing that the "new" or "soft" paternalism of scholars such as Jolls and Sunstein is not without risk on that famously slippery slope); Mario J. Rizzo \& Douglas G. Whitman, Paternalist Slopes, 2 N.Y.U. J.L. \& LIBERTY 411 (2007) (arguing that policymaking based on paternalism should be considered with trepidation). 
improve decision making. ${ }^{\wedge 4}$ I am here focused on debiasing to decrease government intervention-fewer barriers between ESI and the exchanges-making paternalism less of an issue (although still a concern). Removing the impediments to those with ESI choosing to purchase insurance on the exchanges - and particularly allowing employers to subsidize that purchase-provides employees with more options regarding the type of health insurance plan that best meets their needs. Once they need to make choices about what type of insurance to purchase, instead of simply allowing employers to make those choices for them, many employees will pursue knowledge that helps them make better decisions about what health plans to purchase. For those who continue to engage in flawed health insurance decision making, the outcome for them will be no different than allowing their employers to select plans that do not fit their needs.

Equally as important to my argument, considering that I here explore how individuals are not behaving rationally when deciding what health insurance to purchase, I am not concerned with nudging all or even most individuals to suddenly engage in rational decision making in this area. Some employers, who for reasons discussed above are more likely to behave rationally when designing their health benefits offered to workers, will nudge employees into the exchanges if distortions caused by tax subsidies and penalties are eliminated. Those who want to diminish their healthcare expenses on behalf of workers or decrease the administrative burden of interacting directly with insurers or administrators will nudge employees in that direction. Whether or not employees presented with new health insurance make better choices about what plans to purchase on the exchanges, more and better choices will then be available to all in the newly expanded markets.

Instead of preserving the overvaluation of ESI, the government also needs to debias to prevent the creation of a second class of citizens who purchase health insurance through the exchanges only because they do not have access to ESI. The ongoing overvaluation of ESI, particularly because most workers fail to understand the tradeoff between wages and health benefits, hurts: (1) workers who overvalue health benefits when making dollar and cents calculations about employment, (2) individuals who purchase insurance that is considered by society to be inferior on the exchanges, and (3) health reform advocates who want robust exchanges

84. Jolls \& Sunstein, supra note 59, at 226 (citations omitted) ("It is a familiar point that choice-preserving remedies of this general nature are valuable because they acknowledge both that individuals have diverse preferences and that planners may err ...."). 
with high participation rates. First, workers who overvalue health benefits are likely to remain in jobs with generous benefits even when presented with other opportunities that have proportionately higher wages that compensate for a decline in health benefits. This also allows employers to pay less in total compensation by maintaining relatively generous health benefits. Second, as long as individuals prefer ESI to comparable policies available on the exchanges, there will be a stigma attached to health insurance that is not connected to employment. This will further exacerbate the socioeconomic differentiation already taking place in the health insurance market and prevent the further commodification of insurance. Third, as long as ESI is overvalued, fewer workers will move from ESI to the exchanges. This means fewer insurance plans offered in the exchanges and at higher costs (either because the pool is riskier or because there are fewer participants to divide administrative expenses among). Again, this hurts those who must purchase insurance in the exchanges because those with ESI can avoid these harms by staying out of the exchanges. I speculate that debiasing will increase the popularity of the ACA as Americans finally gain familiarity with a health insurance system that includes, but is not reliant on, ESI.

While tax subsidies and penalties may be framed as protecting employees' choice of ESI, if ESI is such an essential component of the compensation package then it will continue to exist largely in its current form even without the advantage of being the only tax-subsidized insurance choice for most employees. This is because employees will migrate to jobs with generous ESI if employers eliminate or degrade their plans. Although a pure free market may not be the goal here, ${ }^{85}$ recent attempts to impede the natural evolution of health reform are an overreaction. In this case, employees should not be separated from the choices available on the exchanges because of the artificial distortion of tax subsidies and penalties. ${ }^{86}$ There is no free choice in health insurance when taxes subsidize ESI heavily and make any other choice unlikely.

85. The private health insurance market is already far from the perfect example of capitalism in action that many make it out to be. A dozen insurance companies cover two-thirds of Americans, and they are heavily regulated by the states already. Robert E. Moffit, Expanding Choice Through Defined Contributions: Overcoming a Non-participatory Health Care Economy, 40 J.L. MED. \& ETHICS 558, 561 (2012).

86. Such access can and should be available to low-income individuals. Switzerland, employing a similar healthcare exchange system that requires every citizen to purchase at least a basic insurance plan and provides subsidies for low-income individuals, now has a $98 \%$ insurance rate, although the government only pays for $24.9 \%$ of total health care expenditures in the country. 


\section{IMPACT OF ESI ATTACHMENT ON ACA}

Much of the news coverage on the implementation of the ACA has focused on questions about whether employers are making plans to move employees into the exchanges. ${ }^{87}$ Scholars and benefit administrators contemplated ways that employers could terminate or gut their health plans and use individual accounts - such as HRAs-as tax-preferred vehicles for subsidizing the cost of premiums for health insurance purchased on the exchanges. ${ }^{88}$ Even worse, they theorized that employers could incentivize select groups of employees to purchase health insurance on the exchanges instead of through their employers. ${ }^{89}$ These methods largely involved savvy employers designing their group health plans to make them undesirable to low-income or less healthy employees (the stick) and then - as necessary-subsidizing the purchase of health insurance on the exchanges with pre-tax subsidies provided to

Mason Felton Reid, Health Care for Low-Income Classes in an Individual Mandate System: Lessons the United States Can Learn from Switzerland, 41 GA. J. INT'L \& COMP. L. 803, 827-28 (2013).

87. See Robb Mandelbaum, Would You Try This Health Insurance Strategy with Your Company?, N.Y. TIMES (June 4, 2014, 11:43 AM), http://boss.blogs.nytimes.com/2014/06/04/ would-you-try-this-health-insurance-strategy-with-your-company/?_r=0 (noting that Zane Benefits, an employee benefits consultant, was offering a product that would allow employers to reimburse employees for the purchase of health insurance on the exchanges and discussing the Obama administration's and IRS's opposition to such an arrangement).

88. See Robert Pear, I.R.S. Bars Employers from Dumping Workers into Health Exchanges, N.Y. Times, May 26, 2014, at A12 ("Many employers had thought they could shift health costs to the government by sending their employees to a health insurance exchange with a tax-free contribution of cash to help pay premiums...."); Amy Monahan \& Daniel Schwarcz, Will Employers Undermine Health Care Reform by Dumping Sick Employees?, 97 VA. L. REV. 125, 130 (2011) ("[E]mployers that pursue a dumping strategy can provide all migrating employees with a contribution to a health reimbursement arrangement ('HRA') equivalent to - or even larger thanthe amount that the employer ordinarily contributes to an employee's coverage. High-risk employees can then use this amount, which is excluded from the employee's taxable income, to purchase coverage on the individual market.").

89. See Jay Hancock, Employers Eye Moving Sickest Workers to Insurance Exchanges, KAISER HeALth News (May 7, 2014), http://kaiserhealthnews.org/news/shifting-employees-to-exchanges (describing how employers might shift workers with high medical costs to the exchanges); David Gamage, Perverse Incentives Arising from the Tax Provisions of Healthcare Reform: Why Further Reforms are Needed to Prevent Avoidable Costs to Low- and Moderate-Income Workers, 65 TAX. L. REV. 669, 693 (2012); Monahan \& Schwarcz, supra note 88; Elizabeth Weeks Leonard, Can You Really Keep Your Health Plan? The Limits of Grandfathering under the Affordable Care Act, $36 \mathrm{~J}$. CORP. L. 753, 774-75 (2011) (discussing the possibility that employers will use required vouchers for low-income employees to push those workers into the exchanges). But cf. Suja A. Thomas \& Peter Molk, Employer Costs and Conflict Under the Affordable Care Act, 99 CORNELL L. REv. ONLINE 56, 57 (2013), http://cornelllawreview.org/files/2013/10/99CLRO56-October.pdf (arguing that additional protections are needed to ensure that employers do not threaten or harass employees for enrolling in coverage on the exchanges under the ACA and costing their employers more). 
employees through HRAs to be used to pay all or part of premiums on these individual policies (the carrot). ${ }^{90}$

Although relying on employer penalties to keep most employers from eliminating their ESI, the administration appears to have been particularly concerned that employers would use HRAs to make taxfavored contributions that employees could use to subsidize in part or whole the purchase of health insurance on the exchanges created under the ACA. Such an arrangement would allow employees to continue to use the tax exclusion given to employers to pay for ESI premiums without any income or payroll taxes applied while purchasing insurance on the exchanges. ${ }^{91}$ As discussed further below, the IRS recently issued additional guidance confirming that this practice will not be permitted, and employers cannot subsidize the purchase of insurance by employees on the exchanges using pre-tax funds. ${ }^{92}$

\section{A. Fears of Employee Dumping}

\section{Employers May Dump All Employees}

The central debate on the implementation of the ACA is whether employers will "pay" or "play" - that is, will employers elect to pay the penalties for not offering health insurance under the ACA instead of continuing to play by offering employer-sponsored group health plans. Most analyses of whether employers will continue to play the game assume that employers are rational actors and that their only motivation for offering ESI is because employees want health insurance and this motivation is balanced by increasing costs not fully offset by wage decreases. Given rising costs for ESI (to employers and employees) and the alternative now offered for employees to purchase insurance on the exchanges, employers are more likely than ever to make rational decisions regarding whether to offer health insurance and what type of health insurance to offer. ${ }^{93}$

90. See Amy B. Monahan, On Subsidies and Mandates: A Regulatory Critique of ACA, $36 \mathrm{~J}$. CORP. L. 781, 796 (2011) (discussing the carrot and stick in the context of individual tax credits and the individual mandate).

91. See Monahan \& Schwarcz, supra note 88, at 161-63 (discussing how employers could use HRAs when dumping employees into the exchanges, including creating a debit card program so employees would not have to pay the premiums up front).

92. Employer Health Care Arrangements, I.R.S., http://www.irs.gov/uac/Newsroom/Employer -Health-Care-Arrangements (last updated Mar. 2, 2015).

93. In addition, research suggests that the imposition of monetary penalties can have consequences other than the anticipated deterrence effect. See generally Uri Gneezy \& Aldo Rustichini, A Fine is a Price, 29 J. LEgAL STUD. 1 (2000) (presenting a field study in which parents 
The possibility that employers may terminate their group health plans or instead incentivize employees to buy coverage on the exchanges is important for several reasons. First, if employees lose ESI, there will undoubtedly be more individuals who receive premium tax credits to purchase insurance on the exchanges or Medicaid. Next, if the employers who drop all coverage had a relatively less healthy workforce, this will drive up the average cost to insure a participant on the exchange (because participants are on average less healthy now) and increase premiums for everyone. Finally, as I have noted repeatedly, most Americans with ESI like their coverage and do not want to lose it. ${ }^{94}$

Any discussion of whether employers may decide to eliminate ESI as a result of the ACA should begin with a look at how the ACA changes employer incentives to offer health insurance to their workers. ${ }^{95}$ Under the ACA, employers with 50 or more full-time employees for over 120 days in a calendar year face a penalty if any of their workers qualifies for a premium tax credit. ${ }^{96}$ Workers are entitled to the premium tax credit if their employer does not offer health coverage or if that coverage is not "affordable" (i.e., the worker's share of the premium for single coverage exceeds $9.5 \%$ of income) or does not provide minimum value (i.e., the worker pays at least $40 \%$ of the cost of the benefits provided under the plan). ${ }^{97}$ If an employer does not offer a group health plan, that penalty for the employer is $\$ 2,000$ per worker after the first 30 workers. ${ }^{98}$ If an employer offers health coverage but it is not affordable or does not provide minimum value, the penalty is the lesser of (a) the aforementioned penalty for employers who do not offer any coverage, and (b) $\$ 3,000$ for each full-time worker who receives the premium tax credit. $^{99}$

To understand why employers may drop their group health coverage as a result, one needs to focus on the reasons that employers offer such

\footnotetext{
were fined for picking up their children late from school to demonstrate that monetary penalties do not always result in deterrence).

94. See Buchmueller, Carey \& Levy, supra note 10.

95. See Nat'l Fed'n of Indep. Bus. v. Sebelius, 132 S. Ct. 2566, 2596 (2012) (holding that the individual mandate is permissible under the federal government's constitutional power to tax even though it is "intended to affect individual conduct"). Similarly, the employer mandate is designed to affect corporate conduct.

96. I.R.C. $\S 4980 \mathrm{H}(2012)$.

97. $I d . \S 36 \mathrm{~B}(\mathrm{c})(2)(\mathrm{C})(\mathrm{ii})$.

98. Id. $\S 4980 \mathrm{H}$.

99. Id. See Buchmueller, Carey \& Levy, supra note 10, at 1525, Exhibit 3; Gamage, supra note 89 , at 693 .
} 
coverage. ${ }^{100}$ First, employers have a comparative advantage as health insurance providers because of tax incentives and economies of scale. ESI premiums are excluded from income and payroll taxes-effectively subsidizing the cost of insurance by one-third for the average worker and more for the highly compensated. Employers are able to provide an adequate risk pool for insurance where the healthy subsidize the sick and to predict health costs from year to year based on past experience. Administrative and marketing costs are largely fixed, so sharing them among a large group allows each participant to pay less for these costs. ${ }^{101}$ Second, workers pay for the benefits indirectly through lower wages. Since health insurance premiums are tax-subsidized and employers arguably are indifferent between paying employees in wages and health benefits, employees typically find this to be a worthwhile tradeoff or are unaware that they are making a tradeoff. ${ }^{102}$ Third, the benefits offered to workers are (mostly) responsive to their demands. Employers balance the needs of a large and sometimes diverse group of employees to achieve the optimal balance of wages and health benefits and provide desirable options for employees. And, if that balance is not always optimal, most employees seem satisfied as indicated by their overwhelming support for their own health insurance arrangements. ${ }^{103}$ These factors motivating employers to offer ESI have not changed. Some, however, argue that the penalties under the ACA for not offering the required insurance are low compared to the costs employers pay for health insurance and provide incentive to discontinue their plans. ${ }^{104}$

Unless employees' attachment to ESI is reduced, employers are unlikely to eliminate their group health plans without substantial financial incentives. If employees continue to overvalue ESI, then simply increasing their wages proportionately as their health plans are eliminated will not be sufficient compensation to satisfy employees. If exchanges are healthy and have comparable options, however, then employees should be more amenable to purchasing insurance on the exchanges if they can purchase plans using pre-tax funds and employer subsidies. The perceived decrease in value resulting from not receiving

\footnotetext{
100. See Buchmueller, Carey \& Levy, supra note 10, at 1523 ("Employers are not currently required to provide health insurance, yet most of them do: Nearly 80 percent of full-time workers are eligible for employer-sponsored coverage.").

101. Id

102. $I d$.

103. Id.

104. See David Pratt, Health Care Reform: Will It Succeed?, 21 ALB. L.J. ScI. \& TeCH. 493, 546 (2011).
} 
those benefits directly through an employer would be mitigated by the financial comparability and the continuing involvement of the employer through funding provided for premiums.

\section{Employers May Dump Some Employees}

Various nondiscrimination and ACA employer mandate provisions are also likely to motivate employers to continue their ESI. ${ }^{105}$ Employers are prohibited from discriminating against workers based on their health status and their income level when administering their group health plans. Prior to the ACA, the Health Insurance Portability and Accountability Act of 1996 amended the Employee Retirement Income Security Act of 1974 (ERISA) to add rules that prevented discrimination based on health status in determining eligibility or premiums for group health plans. ${ }^{106}$ These restrictions do not, however, require an employer or an insurance company to offer a particular type of benefit or level of coverage in a group health plan. ${ }^{107}$ The ACA's nondiscrimination

105. Group health plans also may not discriminate in favor of more highly compensated workers in determining enrollment eligibility or benefits for group health plans, or they risk having the highly compensated forfeit the valuable tax exclusion for premium contribution. I.R.C. § 105(h) (2012). The ACA extends this prohibition beyond self-insured plans to more traditional insured products. PPACA, Pub. L. No. 111-148, sec. 1001, § 2716, 124 Stat. 119, 135 (2010) (codified as amended at 42 U.S.C. $§ 300$ gg-16 (2012)). Employers can use eligibility criteria that have a discriminatory impact on less highly compensated workers, however, or simply raise premiums. See Monahan \& Schwarcz, supra note 88, at 187 (stating that distinguishing among employees based on geographic restrictions, for example, would be acceptable). But see Robertson, supra note 6, at 290-91 ("The IRS has preserved an ultimate discretion to examine plans pragmatically based on a finding of discriminatory impact, regardless of the mechanism.").

106. Health Insurance Portability and Accountability Act (HIPAA), Pub. L. No. 104-191, sec. 101(a), § 702, 110 Stat. 1936, 1945 (1996) (codified as amended at 29 U.S.C. § 1182 (2012)).

107. Employee Retirement Income Security Act (ERISA), Pub. L. No. 93-406, § 702(a), 88 Stat. 829 (1974) (codified as amended at 29 U.S.C. § 1182(a) (2012)). ERISA § 702(a), provides:

[P]aragraph (1) [of this statute] shall not be construed-(A) to require a group health plan, or group health insurance coverage, to provide particular benefits other than those provided under the terms of such plan or coverage, or (B) to prevent such a plan or coverage from establishing limitations or restrictions on the amount, level, extent, or nature of the benefits or coverage for similarly situated individuals enrolled in the plan or coverage.

Id.

ERISA $\S 510$ further provides:

It shall be unlawful for any person to discharge, fine, suspend, expel, discipline, or discriminate against a participant or beneficiary for exercising any right to which he is entitled under the provisions of an employee benefit plan, this title, section 3001, or the Welfare and Pension Plans Disclosure Act [(29 U.S.C.A. 301 et seq.)], or for the purpose of interfering with the attainment of any right to which such participant may become entitled under the plan, this title, or the Welfare and Pension Plans Disclosure Act.

Id. $\S 510$ (codified as amended at 29 U.S.C. § 1140 (2012)). See generally McGann v. H \& H Music Co., 946 F.2d 401, 404 (5th Cir. 1991) (requiring a showing of discriminatory intent rather than 
provision is similar to those already contained within ERISA. ${ }^{108}$ This failure to require specific benefits and levels of coverage is where the opportunity to selectively dump employees under the ACA finds an opening.

The application of penalties if an employer fails to offer ESI to part of its workforce will, in certain circumstances, also help to prevent selective dumping of workers into the exchanges. The $\$ 2,000$ penalty for failing to offer a group health plan is assessed based on the employer's number of full-time workers - not the number of employees excluded from coverage. ${ }^{109}$ The penalty, however, only applies if employers do not offer employees coverage. ${ }^{110}$ It does nothing to prevent an employer from offering unaffordable coverage to a set of workers that would allow them to qualify for subsidies on the exchanges. $^{111}$ The $\$ 3,000$ penalty for offering these employees unaffordable coverage is based on the number of employees receiving the premium tax credit and limited by the maximum employer mandate penalty. ${ }^{112}$

The structure of the ACA also encourages employers to drop lowincome employees. ${ }^{113}$ David Gamage claims that the "ACA will induce employers to stop offering 'affordable' health insurance to at least some

effect where employer reduced coverage for AIDS and AIDS-related illnesses from $\$ 1,000,000$ lifetime maximum to $\$ 5,000$ after plaintiff filed a claim).

108. See PPACA, sec. 1201, § 2705; Monahan \& Schwarcz, supra note 88, at 146 (noting that the ACA's provision is "largely duplicative" of HIPAA's prohibition and emphasizing that only direct discrimination is truly prohibited).

109. Gamage, supra note 89, at 693.

110. Id. at 694 .

111. Id.

112. Id.

113. Concerns about employers dropping health coverage only for low-income workers are well-founded based on a comparison with changes to private pensions after the government entered with a public program to meet minimum retirement income needs. The Social Security Act of 1935 created a basic public pension program for workers based on years of service and wage rate, allowing private pension plans to focus on more highly compensated workers. COLIN GORDON, New Deals: Business, Labor, AND Politics in AmericA, 1920-1935 2-3 (1994). Employers were left to fill the gap between Social Security payments and the amount employees wanted and needed for retirement. WOOTEN, supra note 8, at 27. Since higher wage earners expected larger pensions, private plans focused mainly on the highly paid by integrating Social Security benefits into their pension calculations (i.e., either excluding from participation or paying a reduced benefit to those who earned less than the maximum wages taxable under Social Security). Id. at 27, 29. Since health plans, like pension plans, are a tool used by employers to retain key employees, it is likely that employers would prefer a stratified system that focused on providing pricier, more comprehensive health coverage to the more highly compensated employees that they seek to retain. See generally Chuck Slusher, Pension Integration and Social Security Reform, 61 Soc. SECURITY BULL. 20, 21 (1998). 
low- and moderate-income employees." "114 The ACA creates a "mismatch... between the tax subsidies available for employersponsored health insurance and those available for the health insurance purchased by individuals." 115 Due to income differences and higher marginal tax rates, more highly compensated workers will receive greater tax breaks through ESI, but low-income workers will receive more valuable tax breaks if they can purchase insurance on the exchanges. ${ }^{116}$

Employees who earn up to $400 \%$ of the federal poverty level will be eligible for a premium tax credit to subsidize the purchase of health insurance on the exchanges. ${ }^{117}$ The amount of the premium tax credits depends on household income, the cost of premiums for the benchmark plan used to determine credits, and the number of eligible family members. ${ }^{118}$ Low-income individuals are expected to contribute somewhere between $2 \%$ and $9.5 \%$ of their incomes towards insurance. ${ }^{119}$ Employees purchasing insurance on the exchanges may also receive cost-sharing subsidies to use towards deductibles, copayments, and coinsurance. $^{120}$ The range in value of tax subsidies available to employees who purchase insurance for a family of four on the exchanges in 2016 is $\$ 4,570$ where household income is $400 \%$ of the federal poverty line to $\$ 18,432$ where household income is only $100 \%$ of the federal poverty line. ${ }^{121}$

These valuable tax subsidies for purchasing insurance on the exchanges, however, are not available if the employee has the ability to purchase "affordable" ESI. ${ }^{122}$ As a result, employees lack the ability to

114. Gamage, supra note 89 , at 671-72; see also Hyman, supra note 16, at 14 ("Another provision in PPACA creates an additional incentive for employers to drop coverage; if the coverage they offer is 'unaffordable,' they must pay an additional penalty. 'Affordable' is defined in terms of the percentage of an employee's household income that must be spent on health insurance premiums. According to one survey, roughly one-third of employers had some workers for whom coverage might be "unaffordable."').

115. Gamage, supra note 89 , at 672 .

116. Id. To further complicate matters, a case pending before the Supreme Court questions whether the ACA permits the IRS to issue premium tax credits to those who purchase insurance through exchanges operated by the federal government instead of state governments. See King v. Burwell, 759 F.3d 358 (4th Cir. 2014), cert. granted, 135 S. Ct. 475 (2014) (upholding IRS rule).

117. Gamage, supra note 89 , at $687-88$.

118. Id. at 687 .

119. Id. at $687-88$.

120 Id. at 688. Low-income workers who purchase insurance on the healthcare exchanges will also benefit from the elimination of cost-sharing for preventive services and general caps on costsharing for other services. Reid, supra note 86, at 827-28. By expanding access and encouraging preventive care, more people will receive basic and routine medical care.

121. Gamage, supra note 89 , at 688 , Table 1.

122. As discussed above, insurance is affordable if it requires an employee to pay less than $9.5 \%$ of household income for a single policy. Id. at 689 . 
choose between tax subsidies on the exchanges and those offered through ESI. $^{123}$ In addition, if an employee has the option of enrolling in affordable ESI (determined based on the cost of single coverage rather than family coverage), the employee's whole family is ineligible for tax subsidies to purchase insurance on the exchanges. ${ }^{124}$ The break-even point to determine when an employee would be better off choosing to purchase insurance on the exchanges is when single household income is between $350 \%$ and $375 \%$ of the federal poverty line (depending on assumptions used). ${ }^{125}$ Employees would thus be better off if employers do not offer ESI to employees earning below the break-even point because they would receive the more valuable tax subsidies.

Scholars and the media at large have also focused on the possibility that employers will selectively push employees with expensive health conditions or those more likely to develop those conditions (high-risk employees) onto the exchanges. In 2011, Amy Monahan and Daniel Schwarcz published an article calling attention to loopholes in the ACA that made it possible for employers subject to the ACA tax penalties to incentivize high-risk employees to purchase insurance on the exchanges, leaving employers to cover low-risk employees at a reduced cost while avoiding individual or employer penalties. ${ }^{126}$ By offering ESI that catered to low-risk employees and then using money in an HRA to subsidize the cost of purchasing more expansive coverage on the exchanges for high-risk employees, employers could save money and ensure that employees had proper coverage for a reasonable cost-at least in the short-term. ${ }^{127}$

Monahan and Schwarcz found that self-insured plans could provide basic, preventative coverage desired by low-risk employees and exclude coverage for costly chronic diseases, and doing so made good economic sense. ${ }^{128}$ Because coverage for high-risk employees would be expensive on the exchange without employer subsidies (and without the low administrative expenses of a group health plan), Monahan and Schwarcz understood that employers would have to pay off these employees to motivate them to drop ESI. The employer could contribute a set amount

\footnotetext{
123. Id. at 690 .

124. Id. at 689 .

125. Id. at 690-91.

126. Monahan \& Schwarcz, supra note 88 .

127. Id. at 128. Premium costs could increase or employer subsidies decline over time, making the cost unreasonable at a later point.

128. Id. at $147-50$.
} 
to an HRA every year for use on the exchange. ${ }^{129}$ Monahan and Schwarcz were primarily worried that "employer dumping of high-risk employees could undermine the exchanges ... by rendering the pool of policyholders seeking coverage in exchanges disproportionately risky relative to the general population." $" 130$

In his responsive article, David Hyman steps back and provides a broader view of why the sky is not likely to fall. ${ }^{131}$ While the employer risk classification that Monahan and Schwarcz explain is possible, Hyman argues that it is not probable (even without the recent IRS prohibition on using HRAs to subsidize the purchase of insurance on the exchanges) because of the difficulty for employers in designing such a system. Employers would need to design a health plan that will attract low-risk employees but not high-risk employees, subsidize exchange coverage enough for high-risk employees to leave ESI, not face employee or public backlash from designing a plan with this goal in mind, and monitor the results - all while bringing health costs down enough to make this effort worthwhile. ${ }^{132}$ Hyman quotes President Calvin Coolidge, who said, "If you see ten troubles coming down the road, you can be sure that nine will run into the ditch before they reach you." "133 He advocates waiting to see whether this problem runs into the ditch and, even if not, dealing with more urgent issues with the ACA first. ${ }^{134}$ As Hyman states, "When comparative institutional imperfection is the rule, leaving well enough alone is often sufficient unto the day."135 And yet the IRS chose to fill the gap in the ACA by preventing employers from subsidizing the employee purchase of health insurance on the exchanges using pre-tax funds provided through HRAs, as discussed below. ${ }^{136}$ That the administration saw ten troubles coming and

129. Id. at 160-62. Because employees cannot pay for any remaining cost of insurance premiums with pre-tax money on the exchange, employers might have to "gross up" these employees to equal these extra costs, but many employees would absorb the cost simply to access improved insurance plans that meet their health needs. Id. at 162-63.

130. Id. at 131 .

131. Hyman, supra note 2.

132. Id. at 89-90.

133. Id. at 91 .

134. Id. at 91-92. Not only does Hyman believe it will be difficult for employers to push highrisk employees onto the exchanges, he questions why this is worse than employers instead dropping their health plan entirely. $I d$. at $95-96$.

135. Id. at 105 .

136. See infra Part III.B. Although the dumping strategy crafted by Monahan and Schwarcz does not require an HRA to succeed, it makes it easier and more likely that an employer will be able to selectively dump high-risk employees. 
chose to address this one immediately is indicative of the importance assigned to protecting ESI.

Much has been made about the potential for employers to selectively "dump" higher risk and more costly employees on the individual exchanges, and there remains a risk of selective dumping. However, several factors incentivize employers to dump coverage of all employees rather than experimenting with selective dumping to achieve an optimal balance of employer cost and employee satisfaction. David Hyman cites nondiscrimination provisions, the complexities of pricing coverage as the size of the pool of insureds decreases, and employee protest as factors pushing employers to an all or nothing calculation. ${ }^{137}$ I would add transaction costs associated with deciding which employees should be dropped and, for large corporations, the negative public reaction that could follow a decision to discriminate against more vulnerable employees.

\section{B. Recent HRA Guidance}

A recent newspaper headline announced I.R.S. Bars Employers From Dumping Workers Into Health Exchanges. ${ }^{138}$ The IRS, which along with the Department of Labor (DOL) and the Department of Health and Human Services (HHS) is responsible for implementing the ACA, has issued guidance prohibiting employers from providing employees with a pre-tax payment to use as a partial or complete subsidy for the purchase of health insurance through the exchanges. ${ }^{139}$

This did not stop the discussion about whether an employer might be able to subsidize employees' purchase of individual health insurance through the exchanges using pre-tax dollars instead of offering its own health plan, thus eliminating or reducing the distorting effect tax subsidies for ESI have on the health insurance market. The IRS responded to this speculation by posting Questions and Answers (Q\&As) to its website that repeated and emphasized that employers will face large penalties if they do so. ${ }^{140}$ This type of arrangement constitutes an "employer payment plan" as detailed in IRS Notice 2013-54 issued on

137. Hyman, supra note 16, at 14.

138. Pear, supra note 88 .

139. Id.

140. Employer Health Care Arrangements, supra note 92. 
September 13, 2013. ${ }^{141}$ These employer payment plans are considered group health plans and are therefore subject to the ACA rules prohibiting annual limits for essential health benefits and cost sharing for preventative care. ${ }^{142}$ They cannot meet these requirements, and therefore such arrangements can result in excise taxes of up to $\$ 36,500$ per employee, per year (\$100 per day) under I.R.C. $§ 4980$ D. ${ }^{143}$

HRAs are typically considered group health plans under ERISA and regulated as such. ${ }^{144}$ IRS Notice 2013-54 defines an employer payment plan as: "(1) health reimbursement arrangements (HRAs), including HRAs integrated with a group health plan; [and] (2) group health plans under which an employer reimburses an employee for some or all of the premium expenses incurred for an individual health insurance policy...."145 Employer reimbursements made to the employee, or payments made directly to an insurance company to cover an employee's premiums for health insurance not sponsored by the employer, are excluded from the employee's income. ${ }^{146}$ A plan where the employer offers an employee cash or after-tax money applicable to health insurance is not considered an employer payment plan.

The ACA amended the Public Health Service Act (PHSA) in two respects relevant here. ${ }^{147}$ Section 2711 of the PHSA prohibits a group health plan (which, as discussed above, includes HRAs) or an insurer offering group health insurance from setting an annual limit on the amount of benefits for an individual. ${ }^{148}$ This prohibition only applies to

141. Id. DOL issued the corresponding Technical Release 2013-03, and HHS will soon issue similar guidance. On January 24, 2013, DOL and HHS also issued FAQs providing guidance on the effect of the Affordable Care Act on HRAs. Id.

142. Id.

143. Id.

144. I.R.S. Notice 2013-54, 2013-40 I.R.B. 287. "The term 'group health plan' means an employee welfare benefit plan to the extent that the plan provides medical care ... to employees or their dependents (as defined under the terms of the plan) directly or through insurance, reimbursements, or otherwise." ERISA, Pub. L. No. 93-406, § 733, 88 Stat. 829 (1974) (codified as amended at 29 U.S.C. $\$ 1191 b(2012))$.

145. I.R.S. Notice 2013-54, at 1, 2013-40 I.R.B. 287, 287.

146. Id. at 2; see I.R.C. § 106 (2012).

147. Section 1001 of the ACA added PHSA $\S \S 2711-2719$. PPACA, Pub. L. No. 111-148, sec. $1001, \S \S 2711-2719,124$ Stat. 119, 131-38 (2010) (codified as amended at 42 U.S.C. $\S \S 300 g g-11$ to -19 (2012)). These market reforms are interpreted by the IRS, DOL, and HHS.

148. Section 2711 of the PHSA provides:

(a) Prohibition

(1) In general

A group health plan and a health insurance issuer offering group or individual health insurance coverage may not establish-

(A) lifetime limits on the dollar value of benefits for any participant or beneficiary; 
"essential health benefits" and not other benefits covered under the plan. ${ }^{149}$ Section 2713 of the PHSA requires non-grandfathered group health plans or insurers offering group health insurance to cover some preventive services without any cost sharing. ${ }^{150}$

(B) except as provided in paragraph (2), annual limits on the dollar value of benefits for any participant or beneficiary. .

(b) Per beneficiary limits

Subsection (a) shall not be construed to prevent a group health plan or health insurance coverage from placing annual or lifetime per beneficiary limits on specific covered benefits that are not essential health benefits under section 1302(b) of [the Patient Protection and Affordable Care Act], to the extent that such limits are otherwise permitted under Federal or State law.

PPACA sec. 1001, § 2711.

149. The ACA defines essential health benefits as follows:

(1) In general.- Subject to paragraph (2), the Secretary shall define the essential health benefits, except that such benefits shall include at least the following general categories and the items and services covered within the categories:

(A) Ambulatory patient services.

(B) Emergency services.

(C) Hospitalization.

(D) Maternity and newborn care.

(E) Mental health and substance use disorder services, including behavioral health treatment.

(F) Prescription drugs.

(G) Rehabilitative and habilitative services and devices.

(H) Laboratory services.

(I) Preventive and wellness services and chronic disease management.

(J) Pediatric services, including oral and vision care.

(2) Limitation.-

(A) In general.-The Secretary shall ensure that the scope of the essential health benefits under paragraph (1) is equal to the scope of benefits provided under a typical employer plan, as determined by the Secretary. To inform this determination, the Secretary of Labor shall conduct a survey of employer-sponsored coverage to determine the benefits typically covered by employers, including multiemployer plans, and provide a report on such survey to the Secretary.

PPACA $\S 1302(b)$.

150. Section 2713 of the PHSA provides:

(a) In General.- - A group health plan and a health insurance issuer offering group or individual health insurance coverage shall, at a minimum provide coverage for and shall not impose any cost sharing requirements for-

(1) evidence-based items or services that have in effect a rating of 'A' or ' $\mathrm{B}$ ' in the current recommendations of the United States Preventing Services Task Force;

(2) immunizations that have in effect a recommendation from the Advisory Committee on Immunization Practices of the Centers for Disease Control and Prevention with respect to the individual involved; and

(3) with respect to infants, children, and adolescents, evidence-informed preventive care and screenings provided for in the comprehensive guidelines supported by the Health Resources and Services Administration. 
Previous guidance indicated that an employer payment plan would fail to meet the annual dollar limit prohibition. The interim final regulations on the prohibition state that if an HRA is integrated with other health coverage that would itself comply with the annual dollar limit prohibition, the HRA does not fail to comply with the prohibition simply because it does not meet the requirement on its own-the combined arrangement qualifies. ${ }^{151}$ Frequently Asked Questions issued by the IRS, DOL, and HHS on January 24, 2013 provided that an HRA is not integrated with primary health coverage offered by the employer unless the HRA is offered only to employees covered by employersponsored primary insurance (meaning ESI). ${ }^{152}$

More technically, the IRS will not allow an employer-provided HRA to be integrated with individual health insurance policies purchased on the exchanges, and the HRA will therefore fail to meet the annual dollar limit prohibition. For an HRA to be considered integrated with employer-sponsored primary insurance that meets the requirements, the employee must actually be enrolled in such primary coverage through the employer. ${ }^{153}$ IRS Notice 2013-54 provides further guidance in the form of Q\&As. It clarifies that any group health plan (including an HRA) used to purchase health insurance on the individual market is not integrated with that individual market plan and therefore violates the annual dollar limit prohibition-"an employer payment plan is considered to impose an annual limit up to the cost of the individual market coverage purchased through the arrangement . . .."154

Similar to the analysis for the annual dollar limit prohibition, a group health plan (including an HRA) that is used to purchase primary health coverage on the individual market is not integrated with that coverage under the ACA's preventive services provision. Since "an employer payment plan does not provide preventive services without cost-sharing

(4) with respect to women, such additional preventing care and screenings not described in paragraph (1) as provided for in comprehensive guidelines supported by the Health Resources and Services Administration for purposes of this paragraph.

(5) for the purposes of this Act, and for the purposes of any other provision of law, the current recommendations of the United States Preventive Service Task Force regarding breast cancer screening, mammography, and preventing shall be considered the most current other than those issued in or around November 2009. PPACA sec. 1001, § 2713 .

151. IRS Notice 2013-54, at 4, 2013-40 I.R.B. 287, 290

152. Id

153. Id.

154. Id. at 6, 289 . 
in all instances," the arrangement fails to meet the preventive services requirement. ${ }^{155}$

At its heart, the guidance states that because HRAs are not considered integrated with individual health insurance plans purchased on the exchanges, employers cannot use the accounts to meet the ACA employer mandate by subsidizing the purchase of health insurance not sponsored by the employers. In effect, the guidance limits most employees to the group health plan or plans selected by their employers (assuming these employers offer health benefits). This is because tax subsidies offered for ESI decrease its cost to employees and make it unlikely that they will purchase insurance in the exchanges without offsetting employer subsidies or government tax incentives. ${ }^{156}$

While the use of individual account plans in health financing has drawbacks, as discussed below, ${ }^{157} \mathrm{I}$ am more concerned about an impediment to their growth that results in further stratification of the health insurance market between the "haves" (those with ESI) and the "have nots" (those without). If used to convey employer subsidies for the purchase of insurance on the exchanges, these plans will increase meaningful choice among health benefits and coverage. In the process, they will move more middle and high-income workers into the exchanges, making them more robust and decreasing any lingering stigma from the lack of ESI.

I see individual accounts as a tool to increase participation in the exchanges created by the ACA. This will result in greater choice for everyone as commercial insurers increase offerings and allow the wealthier, healthier workers pushed onto the exchanges to help subsidize the others, as any successful insurance system requires.

\section{THE DEFINED CONTRIBUTION PARADIGM}

While employees have had a longstanding attachment to their ESI, they have in recent years seen a complete transformation of their employee benefits brought about by the shift to defined contribution, or individual account, plans providing retirement income, college savings, and, increasingly, health financing. These accounts have allowed employees to customize their benefits in ways not previously available. Furthermore, employees value the freedom of choice and the possibility

\footnotetext{
155. Id.

156. See supra Part III.A.2 (discussing the incentives for low-income employees to purchase insurance in the exchanges under the ACA).

157. See infra Part IV.A (describing the establishment of the defined contribution paradigm).
} 
that if their investments are fruitful or they curtail their spending through the accounts, then they can reap the rewards in greater funds available for retirement or lower medical expenses.

In the decades following the passage of ERISA, employers largely shifted from offering defined benefit pension plans, which provide an employer-funded, fixed sum paid at regular intervals to employees only after retirement, to defined contribution plans, which provide employees with an individual account funded by both employers (at times and in fluctuating amounts) and employees. Unlike with defined benefit plans, employees with defined contribution plans own and control funds immediately and can access them in times of financial hardship prior to retirement or receive them in a lump sum at that point. ${ }^{158}$ Much has been made by scholars of the resulting shift in risk from employers to employees. ${ }^{159}$ With defined benefit plans, the employer bears most of the risk because it is obligated to pay a fixed sum to the retiree for as long as he lives, regardless of poor investment results for the money that the employer has set aside to fund the annuity-type payments or the unexpected longevity of the retiree and resulting increase in the number of payments. With defined contribution plans, however, the employer makes a one-time payment (and the amount can change based on business performance or the employer's whims) and has no subsequent obligation to the employee. Yet employees, in spite of the risk shift, have become attached to their individual accounts, in large part because they fit with the American narrative of individual choice and ownership. ${ }^{160}$

158. See WoOTEN, supra note 8, at 271-72 (noting how since ERISA, defined contribution plans (especially $401(\mathrm{k})$ plans) have become the "primary retirement savings vehicle for privatesector workers ... [which] may be changing the function of the private pension system").

159. See HACKER, supra note 24, at 112-13 (arguing that even though investment returns for defined benefit plans only narrowly exceeded those for defined contribution plans in a study, "the central issue for retirement security isn't the return, but the risk" since defined benefit plans "forced savings," were managed by investment professionals, and pooled risks across workers); EDWARD A. ZELINSKY, THE ORIGINS OF THE OWNERSHIP SOCIETY: HOW THE DEFINED CONTRIBUTION PARADIGM CHANGED AMERICA 5-30 (2007) (analyzing the proper allocation of retirement-related risks, which he categorizes as investment risk, funding risk, and longevity risk, and reward between employers and employees and finding that concerns over the shift in risk to employees are missing the "appeal" of individual accounts).

160. See ZELINSKY, supra note 159, at 100 (Account holders "must earn income and then save it through salary reduction or other kinds of contributions to obtain what is conventionally thought to be public support in the form of tax subsidies for these accounts ... [reconciling] public subvention and private ownership in a particularly American and historically precedented fashion."); $c f$. Suzanne Cosgrove, More Choices; Company Health-care Plans Let Workers Tailor Insurance Coverage, CHI. TRIB., Oct. 23, 2005, at 5 ("“Freedom of choice' among health-care providers, 'that's what has fueled the market' and its changes in recent years." (quoting Joel Shalowitz, director of the 
The defined contribution revolution then expanded to health financing. As discussed below, flexible savings accounts (FSAs), medical savings accounts (MSAs), health reimbursement arrangements (HRAs), and health savings accounts (HSAs) all developed and collectively grew in popularity. ${ }^{161}$ Employees gained the freedom of choice - the ability to customize their package of employer-sponsored health benefits - to some extent. ${ }^{162}$ Although employees were still limited to the offerings of employers within the cafeteria plans, they could theoretically choose from an increasing array of group health plans with varying levels of coverage and related tax-preferred individual accounts for reducing the cost of deductibles, co-payments, and coinsurance or even covering routine expenses until high-deductible health plans kicked in at the designated threshold. Along with the freedom and customization provided by the new "ownership society," 163 however, came the incentive to participate in managing and containing health expenses. $^{164}$

Yet the advance of defined contribution plans for financing healthcare may have hit a wall with the recent IRS guidance that penalizes employers that use pre-tax funds to subsidize the purchase of health insurance by employees on the new exchanges like they do to subsidize the purchase of health insurance by employees through the employer. Not only does this show the exceptionalism of health among employee benefits, but it also shows how the ongoing fight to preserve ESI in its current form is impeding the so-called shift to consumer-driven health plans in health financing.

health industry management program at Northwestern University's Kellogg School of Management)).

161. See ZELINSKY, supra note 159, at 58-64, 81-84 (giving background on extension of defined contribution revolution).

162. See Wendy K. Mariner, Can Consumer Choice Plans Satisfy Patients?, 69 BrooK. L. REV. 485, 499-500 (2004) (suggesting that "consumer-choice plans" are desirable to participants and may influence health policy, but "merely offering a choice of plans does not guarantee significantly lower costs, better quality or patient satisfaction"); see also Burwell v. Hobby Lobby Stores, $134 \mathrm{~S}$. Ct. 2751, 2799 (2014) (Ginsburg, J., dissenting) (arguing that "the decisions whether to claim benefits under the plans are made not by Hobby Lobby or Conestoga, but by the covered employees and dependents, in consultation with their health care providers").

163. ZELINSKY, supra note 159, at xiii.

164. See Mariner, supra note 162, at 504-05 (arguing that individual account plans require employees to decide how much to spend on healthcare and what type of care to purchase as well as to deal with the repercussions of errors in judgment); see also BEATRIX HOFFMAN, HEALTH CARE FOR SOME: RIGHTS AND RATIONING IN THE UNITED STATES SINCE 1930195 (2012) (explaining that President Bush focused on forcing consumers to control medical costs with tools such as higher deductibles). Co-payments, co-insurance, and higher deductibles all help place the onus of cost containment on workers. 
Beginning in 2017, the ACA will allow states to permit all employers to participate in the exchanges, and employers could then use cafeteria plans to allow employees to use pre-tax funds to purchase their insurance on the exchanges. ${ }^{165}$ I argue, however, that if the Obama administration refused to allow such a defined contribution model of health insurance, it is likely that the states will follow suit. The same pressures based on historical attachment to ESI that caused the IRS to issue its recent HRA guidance will prevent the states from taking advantage of this opportunity under the ACA. A reversal of the federal policy on HRAs, however, would open the door for the states to implement a defined contribution model of health financing and devalue ESI.

\section{A. Establishment of the Defined Contribution Paradigm}

Beginning with the shift to defined contribution pension plans (including individual retirement accounts or "IRAs" and 401(k)s) ${ }^{166}$ and moving into new vehicles to finance healthcare expenses, Americans have increasingly been exposed to tax-favored individual accounts that allow them to own and control their social welfare benefits. ${ }^{167}$ With advantages for employees that include the freedom to customize benefits used to finance their retirement income, health, and education needs, Americans have expressed satisfaction with these new forms of welfare spending. Employers too have supported the movement to a defined contribution paradigm, though as much in a search for a cost-

165. PPACA, Pub. L. No. 111-148, § 1515(a), 124 Stat. 119, 258 (2010) (codified as amended at I.R.C. § 125(f) (2012)). Section 1312(f)(2)(B) of the ACA also provides that:

(i) In general.-Beginning in 2017, each State may allow issuers of health insurance coverage in the large group market in the State to offer qualified health plans in such market through an Exchange. Nothing in this subparagraph shall be construed as requiring the issuer to offer such plans through an Exchange.

(ii) Large employers eligible.- If a State under clause (i) allows issuers to offer qualified health plans in the large group market through an Exchange, the term "qualified employer" shall include a large employer that elects to make all full-time employees of such employer eligible for 1 or more qualified health plans offered in the large group market through the exchange.

PPACA § 1312(f)(2)(B) (codified as amended at 42 U.S.C. § 18032(f)(2)(B)(2012)).

166. An IRA is a trust or custodial account, established for the exclusive benefit of an individual or his or her beneficiaries, by an individual, employer, or by an employee association. I.R.C. § 4082(a)-(b) (2012). A 401(k) is a trust that allows an employee to defer the receipt of compensation in exchange for tax-free contributions to the trust. Id. §§ 401(k)-1(3)(B), 401(k)-1(4)(iii).

167. See Fred T. Goldberg, Jr. \& Susannah Camic, Tax Credits for Health Insurance, 37 J. L. MED. \& ETHICS 73, 75 (2009) ("[H]ealth insurance coverage and the tax system have been deeply entangled for more than half a century. This co-dependence has been expanded substantially during the past several decades with an exponential growth in complexity."). 
containment measure as an arrangement that employees value. Before evaluating the positive and negative aspects of the defined contribution revolution, ${ }^{168}$ I will briefly relay the historical shift to individual accounts in employee benefits and particularly how these accounts have changed employees' experience with financing their healthcare costs.

The defined contribution paradigm has its roots in the shift by employers from sponsoring defined benefit pension plans to instead (or at times, in addition) sponsoring defined contribution pension plans. For years, scholars focused on pensions and mourned the loss of many defined benefit pension plans, which provide employees with regular fixed payments made during retirement typically based on salary and years worked for the employer. ${ }^{169}$ Caused by the decline of unions and changing worker expectations and accelerated by the new mandates ERISA placed on defined benefit plans, employers swiftly shifted to defined contribution pension plans. Under defined contribution plans, employers provide employees only with a set contribution, typically a percentage of salary, and then leave it to employees to make investment selections and bear the risk of poor performance on the markets. An employee receives a lump sum at retirement and is then free to use the money as he sees fit.

Assuming an equivalent employer contribution to either a defined benefit or defined contribution plan (although employers typically reduce contributions when the shift to defined contribution plans occurs), the

168. Employees, intoxicated with the idea of owning and controlling their retirement funds immediately ushered in an era of defined contribution accounts in social welfare benefits. See ZELINSKY, supra note 159, at xiii ("In its own way, the emergence of the defined contribution paradigm has been a revolution, a revolution without a mastermind and without a cataclysmic event, but a revolution nonetheless which has, step-by-step, without fanfare, cumulatively transformed tax and social policy in fundamental ways."); see also Amy B. Monahan, The Promise and Peril of Ownership Society Health Care Policy, 80 TUL. L. Rev. 777, 778 (2006) ("The ownership society generally refers to a society in which individual ownership of assets is encouraged and where individuals are 'in control of their own lives and destinies' and not dependent on handouts.").

169. See, e.g., Stephen F. Befort, The Perfect Storm of Retirement Insecurity: Fixing the ThreeLegged Stool of Social Security, Pensions, and Personal Savings, 91 MinN. L. REV. 938, 987 (2007) ("The shrinking minority who are covered by a defined benefit pension plan are seeing their employers increasingly renege on pension plan commitments. The growing minority offered an employer-sponsored defined contribution plan are seeing their potential nest eggs diluted by inertia, job-change leakages, and an over-concentration in company stock."); Janice Kay McClendon, The Death Knell of Traditional Defined Benefit Plans: Avoiding a Race to the 401(k) Bottom, 80 TEMP. L. REV. 809, 813 (2007) ("With the abandonment of defined benefit plans, employees are left with defined contribution plan coverage that provides minimal benefit accruals during working years and no fixed benefit in postretirement years."); Edward A. Zelinsky, The Defined Contribution Paradigm, 114 YALE L.J. 451, 533-34 (2004) ("However, the movement from the defined benefit framework to the defined contribution paradigm will, in the long run, prove problematic for some, perhaps many, employees by shifting from their employers to them the investment, funding, and longevity risks associated with retirement savings.”). 
tradeoff an employee faces is between risk and choice. Under defined benefit pension plans, employees cannot decide how the money that will fund their pensions is invested. This is because even though they have entitlements to the benefits once vested, they do not own or have possession of the funds until they are taken from the joint trust account and paid out, typically as annuities during retirement. Defined contribution plans, however, allow employees to see the money in their individual accounts, decide how to invest it (as most plans now allow), ${ }^{170}$ and access the money at any point after retirement (and frequently while working with the increasing practice of dipping into such plans for loans during working years).

As a result of increasing employee familiarity with defined contribution pensions and employer incentives to reduce premiums for their group health plans, ${ }^{171}$ defined contribution (or individual account) arrangements also became a fixture in healthcare financing. In the 1980s, the flexible spending account (FSA) was introduced. Through IRC Section 125, Congress allowed employees to choose to receive either taxable income or "purchase" fringe benefits through a "cafeteria plan" using pre-tax funds. ${ }^{172}$ Employees increasingly used FSAs to reduce the cost of co-payments, deductibles, and co-insurance associated with their health insurance plans. ${ }^{173}$ One notable feature of FSAs is that account holders forfeit any remaining balance if it is not used for medical

170. See ERISA, Pub. L. No. 93-406, § 404(c)(1)(A), 88 Stat. 829 (codified as amended at 29 U.S.C. § 1104(c)(1)(A) (2012)).

171. None of this implies that defined benefit plans are extinct in this country. In the public sector, they are very much alive - although they are suffering from serious ailments as a result of state and municipal budget shortfalls and political arguments that they are too costly and too generous compared to private sector pension benefits. See ZELINSKY, supra note 159, at 78-81, 140 ("It is no surprise that public employment is the last bastion of traditional defined benefit pensions since public employment is also the last bastion of unionism."). Indeed, many companies still sponsor defined benefit pension plans. Id. at 31 ("Almost three-quarters (3/4) of the companies listed in the S\&P 500 sponsor defined benefit plans."). Employers continue to slowly shift employees to defined contribution plans, and the remaining defined benefit plans frequently use cash balance accounts that give employees the feeling of individual ownership. Id. at 31-32 (describing the decrease in both the number of defined benefit plans and the number of participants and noting that the remaining plans have largely "switched to the cash balance configuration which mimics the individual account paradigm"). 401(k) plans and IRAs flourish. Id. at 32 (approximately $40 \%$ of private sector employees participate in defined contribution plans, which is double the rate of participation in defined benefit plans).

172. ZELINSKY, supra note 159, at 59 ("The FSA thus further acclimated working Americans to the individual account experience, broadening that experience beyond retirement savings."). See Daniel C. Schaffer \& Daniel M. Fox, Tax Law as Health Policy: A History of Cafeteria Plans 19781985, 8 AM. J. TAX POL'Y 1, 56 (1989) (chronicling legislative history of Section 125 and concluding that "health policy, and indeed any social policy made through tax law is likely to be badly made").

173. ZELINSKY, supra note 159 , at 59 . 
expenses incurred by the end of the year-causing some to make qualified purchases that may not be necessary if they risk otherwise losing the funds. ${ }^{174}$

The medical savings account (MSA), modeled on the IRA, took the defined contribution revolution in healthcare financing further. Established in the IRC by the Health Insurance Portability and Accountability Act of $1996,{ }^{175}$ an individual with an MSA makes taxdeductible contributions to the account that grow and are applied (still tax-free) to pay for medical expenses for the account owner and his family. Only the self-employed and employees of small employers with fifty employees or less were eligible to establish an MSA, and they had to be used in combination with "high deductible" medical insurance to protect against large medical expenses. No new MSAs could be established after December 31, 2007, unless an employer already had a program, but the MSAs led to other health financing accounts. ${ }^{176}$

As the shift to the defined contribution paradigm continued, insurance companies adapted the MSA to lobby the IRS for the health reimbursement arrangement (HRA), added to the IRC in $2001 .^{177}$ An HRA is an employer-funded vehicle for reimbursing employee medical care expenses. ${ }^{178}$ Similar to the MSA, these individual accounts reimburse routine medical expenses up to a level chosen by the employer and then traditional health insurance takes over payment for expenses once the HRA runs dry. ${ }^{179}$ If an employer self-insures, all health coverage can be reimbursed through the HRA, but this is less common. $^{180}$ The HRA can reimburse medical expenses for the employee, his or her spouse, and dependents (including children up to

174. Barry Kozak, New Health Savings Accounts Promote Consumer Driven Health Care, 18 CBA REC. 58, 58 (2004).

175. A medical savings account, or Archer MSA, is a trust that is coupled with a high-deductible health plan and created exclusively for the purpose of paying medical expenses. Withdrawals from the account are tax-free, as long as they are used to pay for the medical care of the account holder, the account holder's spouse, or a dependent. I.R.C. $\S \S 220(\mathrm{c})(1)(\mathrm{A}), 220(\mathrm{~d})(1), 220(\mathrm{~d})(2)(\mathrm{A}), 220(\mathrm{f})$ (2012); HIPAA, Pub. L. No. 104-191, sec. 301(a), § 220, 110 Stat. 1936, 2037 (1996).

176. ZELINSKY, supra note 159 , at $60-61$.

177. HRAs reimburse qualified medical expenses. See I.R.C. § 213(d). They must comply with Sections 105 and 106 of the Code. See id. $\S 105,106$.

178. I.R.S. Notice 2013-54, 2013-40 I.R.B. 287; see I.R.C. § 213(d).

179. I.R.S. Notice 2013-54, 2013-40 I.R.B. 287.

180. ZELINSKY, supra note 159, at 81-82; see also I.R.S. Notice 2002-45, 2002-28 I.R.B. 93; Rev. Rul. 2002-41, 2002-28 I.R.B. 75. 
age 27) up to the maximum allowance. ${ }^{181}$ The reimbursements are not taxable. ${ }^{182}$

In 2003, the advent of the health savings account (HSA) expanded the reach of individual accounts in healthcare and removed many of the restrictions. ${ }^{183}$ HSAs are a method of financing healthcare that includes both tax-favored contributions made to an individual account and a highdeductible health plan (HDHP). ${ }^{184}$ Employees bear the full cost of any health expenses paid after the account runs dry and before the threshold triggering the HDHP is met. ${ }^{185}$ Any individual with a high-deductible health plan as their only health insurance or plan may make taxdeductible contributions to an HSA. ${ }^{186}$ An HDHP is a plan with a minimum annual deductible in 2014 of $\$ 1,250$ for a single person and $\$ 2,500$ for a family with a maximum annual deductible of $\$ 6,350$ for a single person and $\$ 12,000$ for a family. ${ }^{187}$ The individual owner of the account can contribute to $\$ 3,300$ in 2014 if single and $\$ 6,550$ on behalf of a family. ${ }^{188}$ Like the MSA, contributions to the HSA are tax-free, funds grow tax-free, and distributions are tax-free if used for eligible expenses. ${ }^{189}$

\footnotetext{
181. I.R.S. Notice 2013-54, 2013-40 I.R.B. 287.

182. Id.

183 Former President George W. Bush touted the benefits of HSAs heavily: "'Health savings accounts all aim at empowering people to make decisions for themselves, owning their own health care plan, and at the same time bringing some demand control into the cost of [health] care ...."' Michael A. Fletcher, Bush Promotes Health Savings Accounts; He Says Plan Would Cut Insurance Costs and Increase Patient Responsibility, WASH. Post, Jan. 27, 2005, at A02. In the first three years after the advent of the health savings account, approximately three million individuals opened HSAs. Jim VandeHei, In Ohio, Bush Touts Health Savings Plan, WASH. Post (Feb. 16, 2006), http://www.washingtonpost.com/wp-dyn/content/article/2006/02/15/AR2006021502296.html. By 2013, over 8 million individuals had HSAs. Michelle Park Lazette, Health Savings Accounts Rising at Healthy Rate, Crain's Cleveland Bus., (June 26, 2013, 9:13 AM), http://www.crains cleveland.com/article/20130623/SUB1/306249988/health-savings-accounts-rising-at-healthy-rate. While MSAs were limited to self-employed or small employers (with 50 or fewer employees), individuals are eligible for HSAs as long as they are enrolled in a high-deductible health plan. I.R.C. $\S \S 220(\mathrm{c})(4)(\mathrm{A}), 223(\mathrm{c})(1)$. For HSAs, such high-deductible health plans have a lower minimum deductible threshold ( $\$ 1,000$ for individuals) than MSAs ( $\$ 1,500$ for individuals). Id. $\S \S$ 220(c)(2)(A), 223(c)(2)(A). Unlike MSAs, HSAs also allowed both the individual and the employer to contribute to the savings account. See id. § 220(c)(1)(A) (limiting eligibility to those whose accounts are established and maintained by the employer or the individual, but not both); id. $\S$ 223(c)(1) (defining as eligible any individual with a high-deductible health plan who is not also covered under another health plan).

184. Monahan, supra note 168.

185. Id. at 780 .

186 I.R.C. $\S 223(c)(1)$.

187. Rev. Proc. 13-25, 2013-21 I.R.B. 1110.

188. Id.

189. ZELINSKY, supra note 159 , at 83-84.
} 
The enrollment of plans combining individual accounts such as HRAs and HSAs with high-deductible health plans has increased dramatically in recent years. ${ }^{190}$ In $2011,17 \%$ of workers with ESI were enrolled in such a plan. ${ }^{191}$ Although more firms offered HDHPs in conjunction with HSAs (18\%) instead of HRAs (7\%), enrollment was roughly equal between the types of plans ( $9 \%$ in HDHPs with HSAs and $8 \%$ in HDHPs with HRAs). ${ }^{192}$ HRAs are less restrictive in the types of HDHPs that can be combined with the accounts and allow employers to keep any remaining funds if an employee leaves the plan or the job. ${ }^{193}$

Defined contribution health plans such as MSAs, FSAs, HRAs, and HSAs have also been called consumer-driven health plans. ${ }^{194}$ This movement purported to put more power in the hands of consumers to design their medical benefits and choose their physicians than had been the case in the managed care era. ${ }^{195}$ Some have questioned the ability of workers to make rational decisions when it comes to choosing their medical plan and utilizing the funds in these accounts. ${ }^{196}$ The ability of workers to make effective decisions about their own medical needs and financing, however, is at the heart of the movement for choice in this area. ${ }^{197}$ This Article's discussion of bounded rationality with respect to ESI does not imply that individuals can never make rational decisions about health insurance purchases. Instead, it signifies only that they are not making rational decisions under the current system of ESI. Without the distorting effects of tax subsidies and historical ties of health

190. M. Kate Bundorft, Consumer-Directed Health Plans: Do They Deliver?, in THE SYNTHESIS ProjeCt, at 1 (Robert Wood Johnson Found., Res. Synthesis Rep. No. 24, 2012), http://www.rwjf.org/content/dam/farm/reports/reports/2012/rwjf402405 (finding that CDHP enrollees are wealthier and have higher levels of education, and healthcare spending declines from $5 \%$ to $14 \%$ with enrollment).

191. Id. at 5 .

192. Id. at 5-6.

193. Id. at $5,9,18$.

194. See Amy B. Monahan, Employers as Risks, 89 CHI.-Kent L. Rev. 751, 765-66 (2014); Mary Crossley, Discrimination Against the Unhealthy in Health Insurance, 54 U. KAN. L. REV. 73, 119-20 (2005) ("Lacking a single definition, the phrase [consumer-driven health care] has come to refer generally to health plans that give employees both greater responsibility for designing their own benefit packages and choosing their providers... as well as greater financial risk for their health-care costs."); see also Russell B. Cate, Note, Move over Managed Care-Health Savings Accounts, Small Businesses, and Low Wage Earners, 4 InD. HeALTH L. REV. 287, 294-95 (2007).

195. See Crossley, supra note 194, at 118-21.

196. See id. at 129-31 (noting fears that consumers lack necessary information to make medical decisions, are unduly influenced by physicians, and will be forced to make decisions in times of great stress due to health crises).

197. See id. at 131 ('Regardless of one's level of optimism regarding patients' competency to make cost-effective medical decisions, however, this competency is indisputably a central premise of consumerism. Without it, patients' decisions may be as likely to harm as to promote their health.”). 
insurance to employment, and with additional education on available health plans and experience gained in the exchanges, there is reason to believe that decision making will improve even if it remains imperfect.

Aside from the ethos of choice inherent in individual account plans, these arrangements have taken hold in health as a cost-containment measure. Unless employees can save money directly by limiting their medical care, they will not have an incentive to reduce healthcare expenses. ${ }^{198}$ Employees are most likely to save by reducing their preventative care and discretionary expenses for minor illnesses. ${ }^{199}$ But employees with individual account plans typically pay more for their health expenses than those with a health plan through their employer that does not include an individual account. Thus, the use of defined contribution plans in healthcare shifts the financial risk to employees for their medical expenses in a similar way that the movement to defined contribution pension plans shifted the financial risk for retirement expenses to employees. ${ }^{200}$

\section{B. Devaluing ESI through HRAs}

Edward Zelinsky's prediction for the future was that "in the private sector, the defined contribution model for retirement, health care and educational savings is entrenched and will continue to expand with little resistance."201 His prediction, however, misses some of the nuances of health insurance and financing. He begins with a basic analogy of defined benefit pension plans to health insurance:

Medical insurance... is the health care analogue to a defined benefit pension. Just as defined benefit plans pool employees and their claims and assign risk and reward to the sponsoring employer, medical insurance pools the insureds into a covered group and allocates risk and reward to the insurer. If those

198. See Monahan, supra note 194 , at $765-66$.

199. Wendy K. Mariner, Social Solidarity and Personal Responsibility in Health Reform, 14 CONN. INS. L.J. 199, 211 (2008) ("Shifting this kind of care out of the defined benefit package trims health plans of their coverage of some non-fortuitous risks ....").

200. Monahan, supra note 194, at 756; Crossley, supra note 194, at 119-20 ("While promising consumers a broader choice of providers and greater control over their medical decisions, consumerdriven plans promise employers cost savings flowing from the combination of greater efficiency in the purchasing decisions of cost-conscious consumers and a shifting of health-care costs to employees.").

201. ZELINSKY, supra note 159, at xvi. "Equally disputatious will be the debate about efforts to expands [sic] the use of HSAs, a debate which addresses the fundamental implications of the defined contribution paradigm: the merits of individual ownership and control, the benefits of risk-pooling, the costs of adverse selection, the distributional consequences of individual accounts." Id. at 137. 
covered by medical insurance in the aggregate spend less on medical care than had been predicted, the difference inures to the insurer; conversely, greater than expected outlays for the insured group are the insurer's problem. Similarly, if the insurer generates more income than anticipated from the investment of premiums, that profit accrues to the insurer-as does poorer than expected investment experience. Within the group of insureds, insurance pools the risks of unexpectedly bad health just as defined benefit plans pool investment, funding and longevity risks for members of the covered workforce. ${ }^{202}$

The main difference between the defined contribution revolution in pension plans and the rise of individual accounts for health financing, however, is that the element of choice is curtailed with health accounts. In the area of pensions, employers gave employees both ownership of the funds and the ability to customize their retirement benefits. Employees with individual accounts to subsidize their medical costs, however, still typically have the choice of one or a small number of health plans that determine what types of health conditions will be paid for by insurance and what types will be the employees' responsibility-tax-subsidized though that responsibility may be. ${ }^{203}$ Employees do not have control over deductibles, co-insurance and co-payments with little chance of customizing either the benefits covered or the extent to which they are covered by insurance. ${ }^{204}$ Employees have ownership of the funds here, but no meaningful choice as to how they will be spent, and "[t]he locus of key decision-making is the central issue in health policy."205 As Amy Monahan writes, the plan design that employees do not control determines their financial (and health) risk. ${ }^{206}$

The opportunity for employers to subsidize the purchase of health insurance on the exchanges by employees was the first opportunity for

202. Id. at 61-62 (citations omitted).

203. Although anyone can utilize an HDHP in combination with an HSA, typically employees utilize the plans made available through their employers if there are any. The more common use of an FSA with a traditional group health plan allows employees a small number of plans to choose from and they are pre-selected by employers.

204. Monahan, supra note 194, at 766. The difference between 401(k) plans and group health plans offered by an employer is that $401(\mathrm{k})$ plans allow employees to customize their retirement savings strategy, but employer health plans do not allow for individual choice. Id. at 768-70.

205. Moffit, supra note 85, at 560, 568 (argues against further consolidation of healthcare financing and regulation and in favor of defined-contribution financing with enhanced "personal choice in health coverage" by individuals).

206. Monahan, supra note 194, at 768-70 ("However, $82 \%$ of firms that offer health benefits offer employees only a single plan, although over half of all workers have a choice of health plans. This results in a sizeable portion of the employee population having only a single 'take it or leave it' health plan option, and increases the likelihood that some employees will continue to face healthinsurance related risks even if they have coverage."). 
defined contribution accounts in health financing to provide choice. Assuming there are meaningful differences between the plans offered on the exchanges, employees would for the first time have full control over benefits covered and levels of coverage. Although some have argued that employers make better decisions when designing or purchasing group health insurance than individual employees would, ${ }^{207}$ that is a concern equally valid in the pension context where individuals are now free to make whatever potentially foolish investment and spending decisions they wish.

Portability is another way in which subsidizing the purchase of employee health insurance on the exchanges would make defined contribution plans in health financing more like pensions. The recent IRS guidance does nothing to deal with worker mobility. ${ }^{208}$ ESI locks employees into jobs because a new employer may not offer any (heavily tax-subsidized) coverage at all or may offer less favorable coverage. ${ }^{209}$ Having an individual market as an alternative is helpful and may convince some employees with less generous health plans to move, but continuing attachment to ESI still locks employees into jobs. Although employees would still risk losing valuable employer subsidies for health insurance if employers are allowed to subsidize the purchase of insurance on the exchanges and employees leave employment, they will not lose their insurance plans. Instead, employees can then make an informed decision about how total compensation packages compare. An employer's contribution to an employee's health insurance premiums will be just one, easily quantified factor in switching jobs. Regardless, fear of change with respect to their health insurance will no longer tie employees to employers.

While the problems with consumer-driven health plans (CDHPs) are well catalogued, ${ }^{210}$ the administration's recent roadblock in the path of defined contribution plans in health financing is important for several reasons. First, it demonstrates the shift in policy from the Bush administration in this area. One could endlessly debate whether these

\footnotetext{
207. See Monahan, supra note 168 , at 818-30.

208. See id. at 807-09 (discussing limitation on worker mobility presented by HSAs and HDHPs as a result of their lack of portability).

209. See id.

210. See id. (cataloguing problems with CDHPs such as adverse selection as the healthy flee to CDHPs and leave other insurance products with poor risk pools and possible poor decision making by consumers with respect to health expenses resulting in financial losses); see also Crossley, supra note 194, at 131-32 (arguing that HSAs, and other "consumerist mechanisms" shift risk for uninsured medical expenses to consumers and may thus disadvantage the unhealthy or those with low incomes as they are forced to ration their healthcare).
} 
individual account plans actually do expand consumer choice or if blocking the use of these plans in this instance preserves consumer choice in favor of ESI (although this choice is of course artificially preserved by tax subsidies). Preventing workers from purchasing health insurance on a thriving exchange, however, would undoubtedly limit the types of coverage available to those workers. Though employers have acted as a useful intermediary, evaluating many health plan designs before winnowing the options for employees, they have different goals when choosing health plans than employees. Individual healthcare needs vary, and so health plans selections should vary accordingly.

Second, this action to prevent workers from using employer subsidies to purchase insurance outside employment through individual accounts hurts individuals on the exchanges. Since employees covered by ESI and kept segregated from the exchanges through this guidance are likely to be, on average, wealthier, there is now socioeconomic segmentation of the health insurance market. Some would argue that this differentiation has existed for decades as some have ESI and some do not, and the ACA has only improved conditions for those who lack ESI through the exchanges. Even so, why not use the opportunity to reduce inequality here? It will only help eliminate the second-class status of those who lack ESI and create more robust exchanges in the long run. Putting aside my feelings about the much-maligned consumer-driven health movement, I see here an opportunity to increase choice and equality in health insurance in the long-term - an opportunity the Obama administration has missed.

The ACA amended the IRC to prevent employers from offering employees pre-tax funds to use to purchase health plans on the exchanges. ${ }^{211}$ An exception was made for small employers eligible to purchase insurance for their employees on the exchanges. ${ }^{212}$ Beginning in 2017, each state can allow those who issue group health plans to sell them on an exchange and large employers to purchase those plans through the exchange. ${ }^{213}$ All employers would then have the option of using cafeteria plans to offer employees pre-tax funds to purchase health insurance on that exchange. ${ }^{214}$

While this would advance the use of defined contribution health financing, it is unlikely that many states will allow large employers to

211. PPACA, Pub. L. No. 111-148, § 1515(a), 124 Stat. 119, 258 (2010) (codified as amended at I.R.C. $\$ 125(\mathrm{f})(3)(\mathrm{A})(2012))$.

212. Id.

213. Id. $\S 1312(\mathrm{f})(2)(\mathrm{B})$ (codified as amended at 42 U.S.C. $\S 18032(\mathrm{f})(2)(\mathrm{B})(2012)$ ).

214. Id. 
follow this path when the federal government has not. States will be subject to the same political pressures to maintain the current ESI system. If the Obama administration could not withstand the pressure, then it is unlikely that individual states will do so. The revocation of the HRA guidance would be the first step to an ongoing experiment with health financing and defined contribution plans. More importantly, it would take us one more step away from ESI.

\section{CONCLUSION}

The ACA is focused on individual choice - as long as that choice is ESI. ${ }^{215}$ The attachment that employees have to ESI is considered to be so important that the Obama administration continues to build protections for ESI into the statute. These protections ignore the facts that: (1) some employees (particularly low-income workers or those with particular health conditions or coverage preferences) would prefer to instead purchase insurance on the exchanges; and (2) it is likely that the majority of employees would be better off in the long-run if the border between ESI and the exchanges was more porous.

The recent HRA guidance prevents a potentially useful innovation in our public-private system of health benefits. Defined contribution plans have been touted for the choice that they permit employees, although critics have focused on the insurance risk that they shift to employees. Here is an opportunity to put the defined contribution revolution to use by moving more middle and high-income workers into the exchanges, improving choice for all on the exchanges and reducing the stigma of insurance purchased outside of the employment relationship. ESI and the exchanges can and will continue to coexist-but when our attachment to ESI gets in the way of innovation in health insurance, it is time to look again at whether our bounded rationality is healthy.

215. See Maher, supra note 27, at 1104 (arguing that the ACA relies on a private insurance system, rejecting other options). 